\title{
Deformation Mechanism of Deposit Landslide Induced by Fluctuations of Reservoir Water Level Based on Physical Model Tests
}

\section{Zihua Jiang}

Hohai University

Huanling Wang ( $\nabla$ wanghuanling@hhu.edu.cn )

Hohai University

Weichau Xie

university of waterloo

\section{Research Article}

Keywords: deposit landslide, reservoir water level fluctuations, physical model test, groundwater, deformation mechanism

Posted Date: February 24th, 2021

DOI: https://doi.org/10.21203/rs.3.rs-227583/v1

License: (9) This work is licensed under a Creative Commons Attribution 4.0 International License. Read Full License 


\title{
Deformation mechanism of deposit landslide induced by fluctuations
}

\section{of reservoir water level based on physical model tests}

\author{
Zihua Jiang ${ }^{1}$, Huanling Wang ${ }^{2 *}$, Weichau Xie ${ }^{3}$
}

1. Institutes of Geotechnical Engineering, Hohai University, Nanjing, Jiangsu 210098, China;

2. Key Laboratory of Coastal Disaster and Defence, Ministry of Education, Hohai University, Nanjing, Jiangsu, 210098, China;

3. Department of Civil and Environmental Engineering, University of Waterloo, Ontario N2L 3G1, Canada

\begin{abstract}
Located in reservoir area of Dahuaqiao Hydropower Station in Lancang River, the Dahua ancient deposit landslide exhibits high possibility of reactivation due to reservoir impoundment. In this study, physical model tests are conducted to investigate the variations of groundwater, deformation, and failure process of the landslide under different fluctuation speeds of reservoir water level. Influence of groundwater on landslide stability when reservoir water level fluctuating is analyzed then. Results indicate that the seepage pressure caused by water level difference can increase landslide displacement. During the dropping process of reservoir water level, the relationship between landslide displacement and water level difference can be described by a power function model. Groundwater has negative effects on stability of landslides, and the damage is characterized by traction landslide. More attentions should be paid on the displacement of the front edge of the landslide during the first rise and drop of reservoir water level. The study provides indispensable information for scheduling reservoir water level in the Dahuaqiao and others similar reservoir areas, thus having vital importance.
\end{abstract}

Keywords: deposit landslide; reservoir water level fluctuations; physical model test; groundwater; deformation mechanism

\section{Introduction}

In reservoir areas, fluctuation of groundwater level caused by change of reservoir water level is one of major factors inducing and reactivating landslides. For example, the landslide occurred on the left bank of the Vajont Reservoir area in Italy during the impoundment period in $1963^{[1-3]}$; the Qianjiangping landslide in the Three Gorges Reservoir in China occurred during the first impoundment in $2003^{[4-5]}$; both the Teton dam failure in the United States in $1976^{[6]}$ and the Malpasset arch dam collapse in France in $1954^{[7]}$ were related to the rapid rise of reservoir water.

There are different opinions of landslides induced by fluctuation of reservoir water level. Jones $^{[8]}$ found that more than $50 \%$ of the landslides in the Grand Coulee Dam reservoir area occurred during the rise of reservoir water level from 1941 to 1953 , and about $30 \%$ of the landslides occurred during the fall of reservoir water level. However, Nakamura ${ }^{[9]}$ analyzed landslides in the reservoir areas in Japan and found that about $60 \%$ of the landslides occurred during the rapid fall of reservoir water level, and about $40 \%$ of the landslides were induced by the rise of reservoir water level. Also, deformations of landslides in reservoir areas are believed to start at the beginning of reservoir operation and last for several years ${ }^{[10-12]}$. 
Fluctuations of reservoir water level will inevitably lead to fluctuations of groundwater level inside a landslide, which is believed to be the main factor inducing landslides ${ }^{[13-17]}$.

Fluctuations of reservoir water level are mainly the results of human control. Compared with random rainfall, the external boundary conditions of the reservoir water level fluctuations are relatively deterministic. Therefore, numerical methods can be used to simulate the impact of reservoir water level fluctuations on the stability of landslides ${ }^{[18-21]}$. However, the reliability of the numerical results depends heavily on the accuracy of the input parameters and the constitutive relationship. Large-scale physical model test is intuitive, and the information system of multi-field evolution can be easily monitored. Thus, it is an important approach to study landslide deformation, failure modes, and mechanism of disaster. For example, Jia et al. ${ }^{[22]}$, Luo et al. ${ }^{[23]}$, He et al. ${ }^{[24]}$, and Wang et al. ${ }^{[25]}$ studied the influence of reservoir water level on landslide stability through physical model tests.

The Dahua landslide is a typical deposit landslide in the reservoir area of Dahuaqiao Hydropower Station in the Lancang River as shown in Fig. 1. The stability of the Dahua landslide is greatly affected by the reservoir water level. At present, the monitoring data show that the Dahua landslide is still creeping because of reservoir impoundment. Therefore, an in-depth analysis of the deformation mechanism of Dahua landslide with different reservoir water level fluctuation rates is of great significance for the safe operation of Dahuaqiao Hydropower Station. In this paper, a large-scale physical model is established using a typical profile of the Dahua landslide, and deformation mechanism of the landslide is then analyzed by model test.

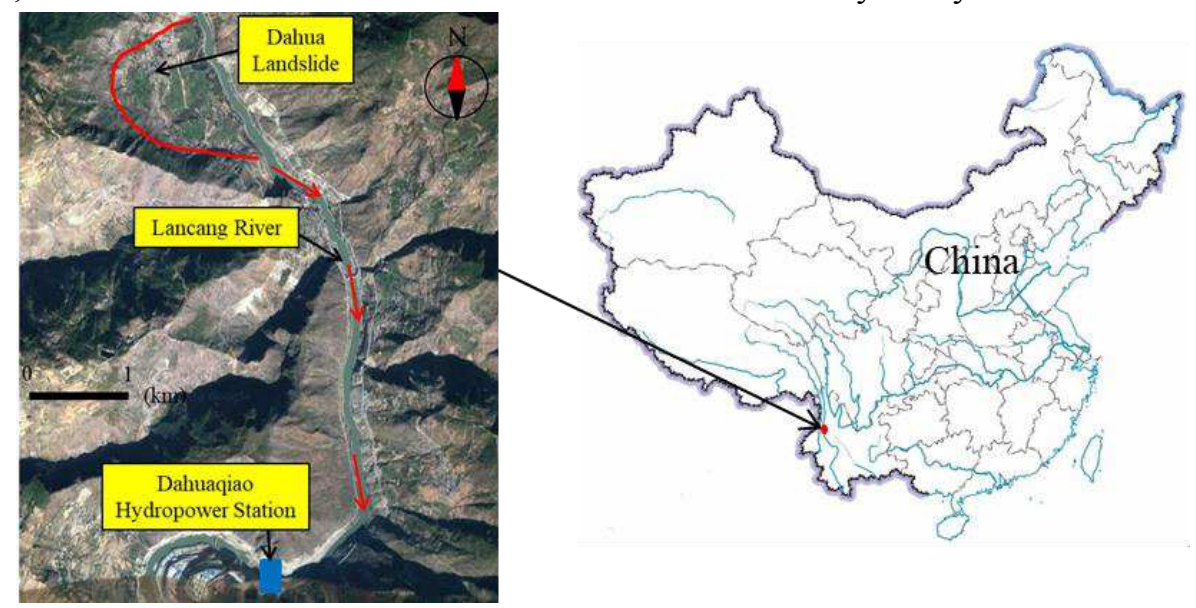

Fig. 1 Site location of the Dahua landslide

\section{Regional Setting of the Dahua Landslide}

\subsection{Regional Topographic and Geomorphic Conditions}

Topographic and geomorphic features of the Dahua landslide are shown in Fig. 2. As can be seen from Fig. 2 (a), the front of the Dahua landslide is the Lancang River, which is surrounded by the steep wall of bedrock, with the shape of "circle chair". The whole landslide is fan-shaped, narrow in front and back, and nearly NS-oriented. The leading edge of the landslide has reached the edge of the Lancang River, forming a slope of 50-60 degrees, and some of the bank slopes are unstable and sliding. According to the topographic features, material composition, borehole data, cause analysis and sliding mechanism, the Dahua landslide was divided into five zones as shown 
in Fig. 2 (a). Typical tensile cracks are distributed on the surface of the landslide as shown in Fig. 2 (b) - 2 (e).
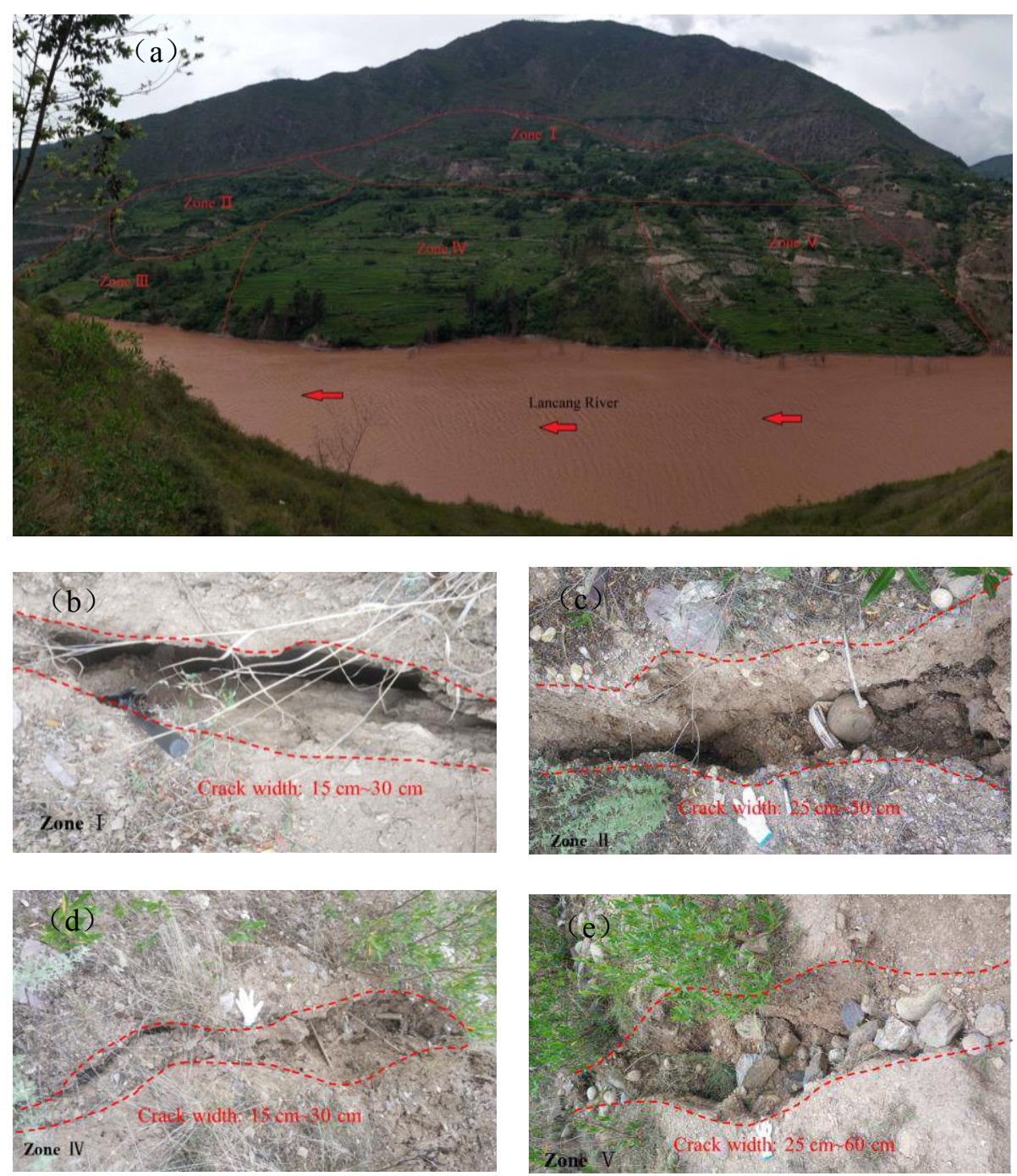

Fig. 2 The topographic and geomorphic features of the Dahua landslide

\subsection{Engineering Geology and Hydrogeological Conditions}

The landslide locates within elevation of $1040-1870 \mathrm{~m}$ and is classified as super large landslide with maximum valley width of $1000 \mathrm{~m}$, area of 1.1 million $\mathrm{m}^{2}$, volume of $4.8 \times 10^{7} \mathrm{~m}^{3}$ (14.4 million $\mathrm{m}^{3}$ in the Zone $\square, 6.3$ million $\mathrm{m}^{3}$ in the Zone $\square, 8.2$ million $\mathrm{m}^{3}$ in the Zone $\square, 14.4$ million $\mathrm{m}^{3}$ in the Zone $\square, 4.3$ million $\mathrm{m}^{3}$ in the Zone $\square$ ). When the reservoir water level reaches the normal water level of $1477 \mathrm{~m}$, the front edge of the landslide body is about $67 \mathrm{~m}$ below the water level. Geological survey indicates that the Dahua landslide is mainly composed of the collapsed earth-rock with a surface layer of $10 \mathrm{~m} \sim 50 \mathrm{~m}$, and the lower bedrock is composed of full and strong weathered purple-red slate. The contact surface of bedrock and earth-rock mixture controls the deformation track of the landslide. Results from borehole exploration show that the sliding surface is generally buried in the depth of $40 \mathrm{~m}$ to $50 \mathrm{~m}$, with maximum of $80 \mathrm{~m}$. 
Before impoundment, the groundwater level in the landslide area is higher than water level of the Lancang River. Therefore, the groundwater in the landslide area is mainly replenished by atmospheric precipitation and discharged into the Lancang River in the form of infiltration and surface runoff. The bedrock fissure water mainly exists in the joint cracks and fault zones of the rock masses and is controlled by the fracture network formed by the fault structure. The average annual rainfall is $973.8 \mathrm{~mm}$, and the distribution of rainfall is uneven during the year. The rainfall from June to September accounts for $71.7 \%$ of the whole year, reaching the peak in July and August.

\section{Large-scale deposit landslide physical model set-up}

\subsection{Physical model test platform}

The schematic diagram of physical model test platform shown in Fig. 3 consists of a model test chamber (1), a reservoir water level control system (2), a monitoring system of multi-physical quantities (3) and a groundwater level control system (4). The model test chamber has a length of $8.0 \mathrm{~m}$, a width of $0.8 \mathrm{~m}$ and a height of $3.5 \mathrm{~m}$. The physical model of landslide mainly includes three parts: bedrock, sliding surface and sliding body.

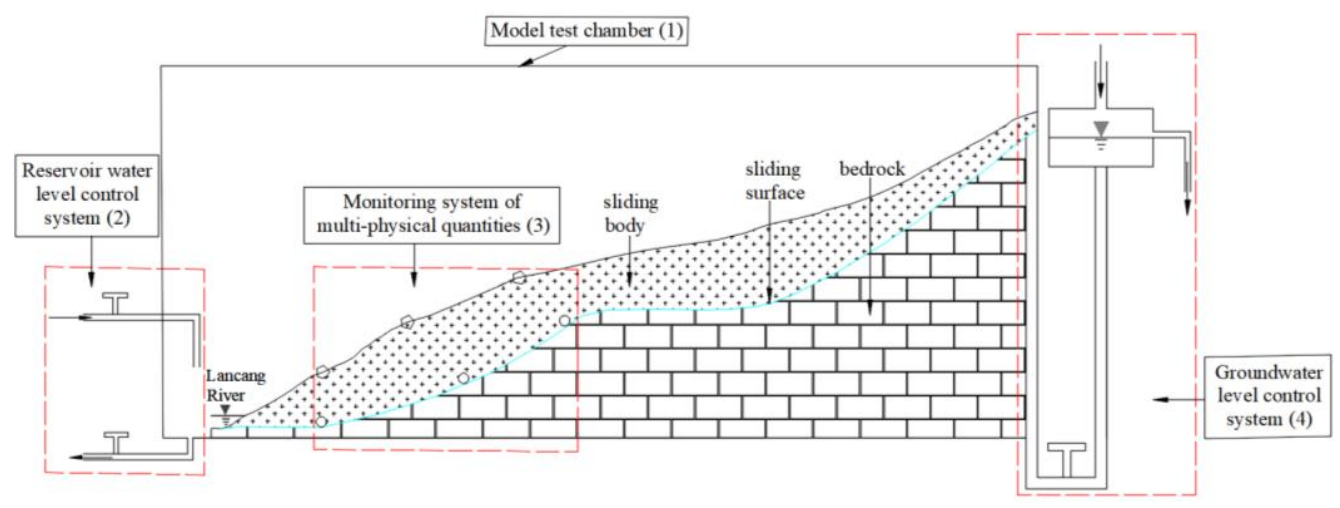

Fig. 3 Schematic diagram of physical model test platform

\subsection{Similar materials}

According to the similarity theory, the gravity acceleration similarity ratio $\left(\mathrm{C}_{g}\right)$, density similarity ratio $\left(\mathrm{C}_{\rho}\right)$ and weight ratio $\left(\mathrm{C}_{\gamma}\right)$ are both 1 , and the geometric similarity ratio $\left(\mathrm{C}_{l}\right)$ is 150 in this landslide physical model. Based on the dimensional analysis method, the similarity ratios of the angle of internal friction $(\varphi)$, cohesion $(c)$, permeability coefficient $(k)$, stress $(\sigma)$, strain $(\varepsilon)$ and speed of reservoir water level fluctuant $(v)$ are determined as $\mathrm{C}_{\varphi}=\mathrm{C}_{\varepsilon}=1, \mathrm{C}_{c}=\mathrm{C}_{\sigma}=150$, $\mathrm{C}_{k}=\mathrm{C}_{v}=\sqrt{150} \approx 12.24$. Parameters of the similar materials of the landslide physical model mainly include geometric similarity ratio, density, cohesion, angle of internal friction, gravitational acceleration and permeability coefficient. The sliding surface material is composed of sand and clay, and the sliding body material is composed of small stones, clay and sand. Table 1 shows the physical and mechanical parameters of the prototype and model landslides acquired by model tests using uniform design method, and the particle gradation curve of prototype and model landslide is shown in Fig. 4. 
Table 1 Physical and mechanical parameters of prototype and model landslides

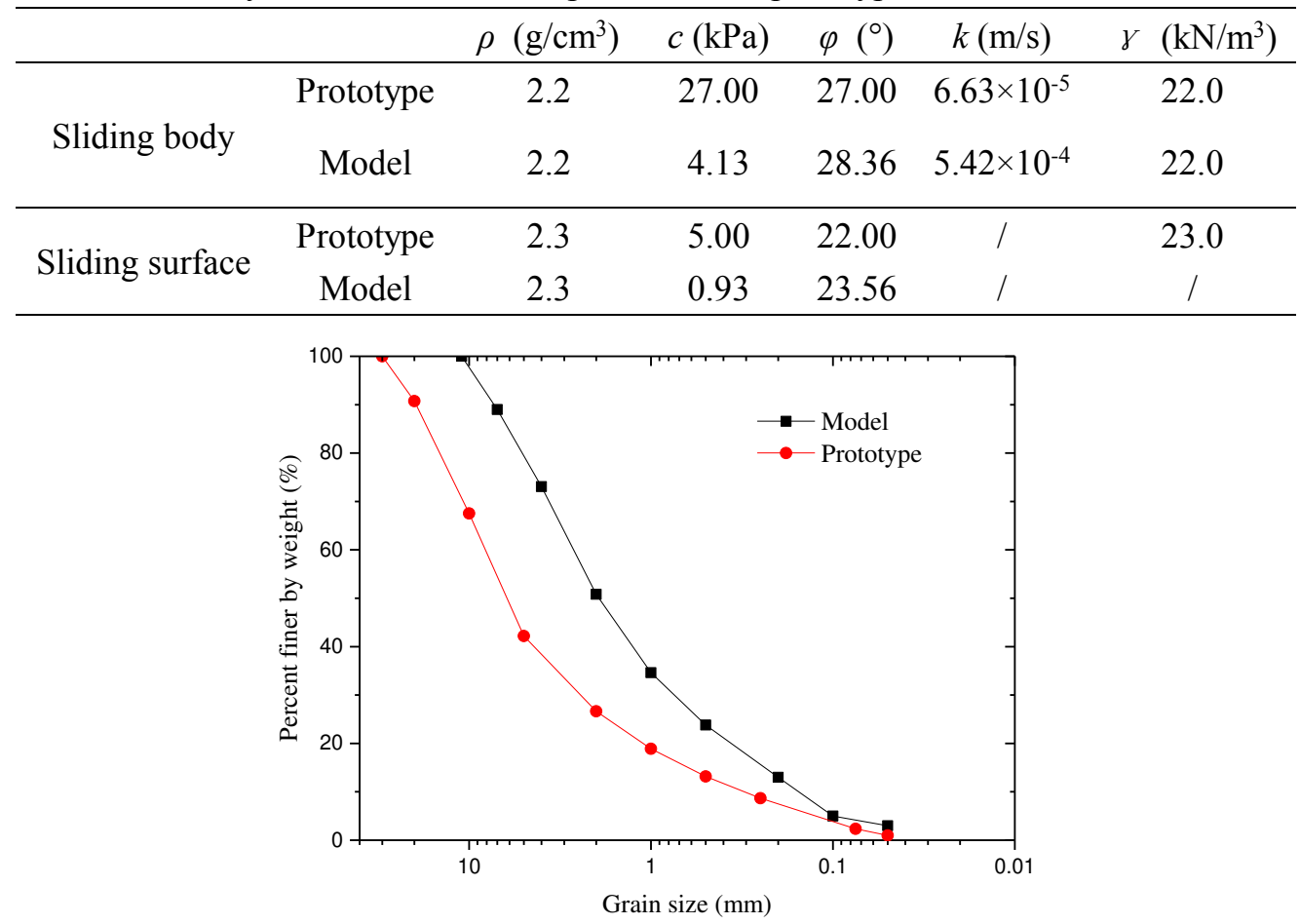

Fig. 4 Particle distribution curve of prototype and model landslide

\subsection{Landslide profile and sensor arrangement}

A typical profile of the Dahua landslide (shown in Fig. 5) was selected for physical model tests. Three pore water pressure sensors were installed on the slipping surface, and three displacement sensors were installed in the sliding body. The area affected by the reservoir water level fluctuations is located mainly in the front edge of the landslide, hence the sensors are arranged mainly in the front edge as shown in Fig. $6\left(\mathrm{p}_{1}, \mathrm{p}_{2}\right.$, and $\mathrm{p}_{3}$ are pore water pressure sensors, and D1, D2, and D3 are displacement sensors).

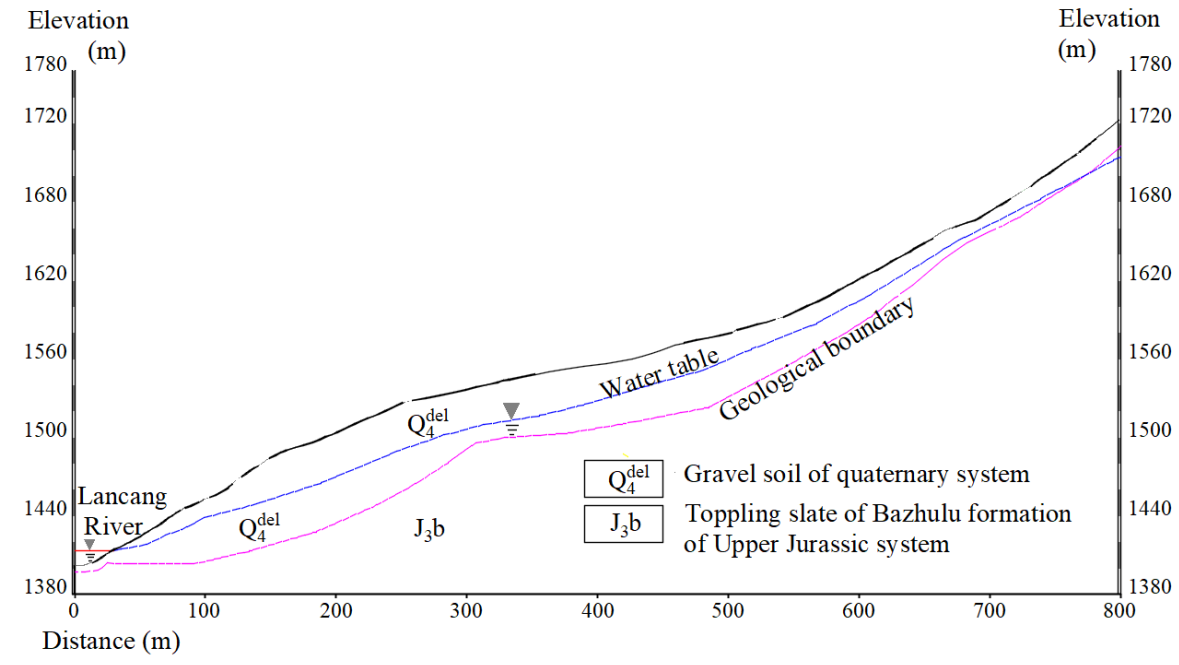

Fig. 5 Typical profile of Dahua landslide 


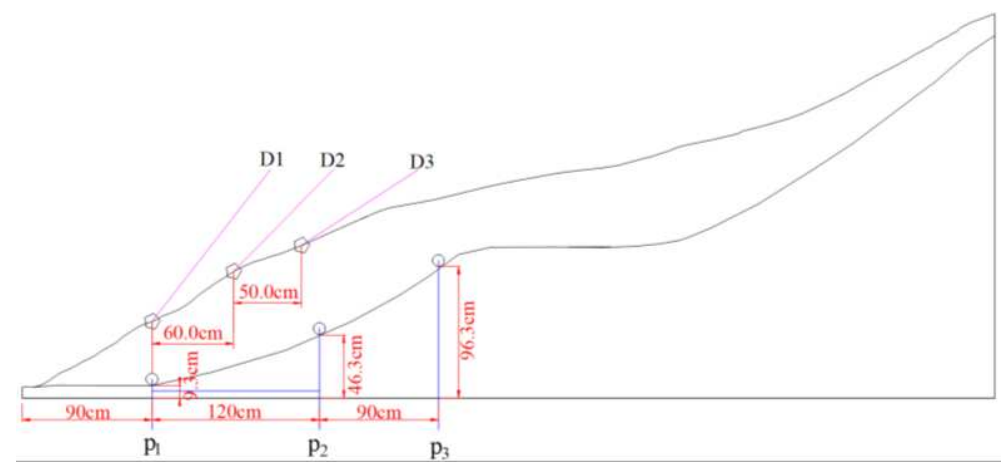

(a) Elevation arrangement of sensors

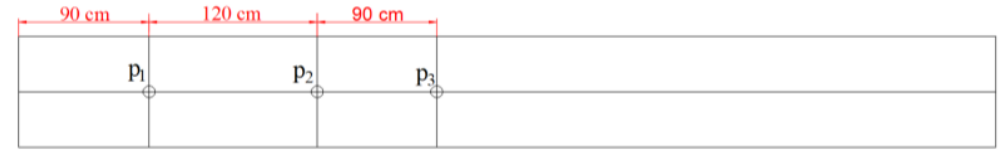

(b) Plane arrangement of sensors for sliding surface

Fig. 6 Arrangement of instruments in the physical model

\subsection{Test scheme}

According to the designed rising speed of the reservoir water level in the Dahuaqiao Reservoir Area, the initial rising speed in the model test is set as $6.43 \mathrm{~cm} / \mathrm{h}$. To study the impact of the rapid drawdown caused by extreme conditions such as mountain flood and dam break on the stability of Dahua landslide, the benchmark of drawdown speed of reservoir water level is set as $25.71 \mathrm{~cm} / \mathrm{h}$. The test scheme is listed in Table 2, and the procedure is shown as follows:

1. In the first test of reservoir water level fluctuations, the rising speed of reservoir water level is $6.43 \mathrm{~cm} / \mathrm{h}$, lasting for $7.00 \mathrm{~h}$, and then, the water level remains unchanged for $4.00 \mathrm{~h}$. After that, the water level starts to decline with falling speed of $25.71 \mathrm{~cm} / \mathrm{h}$, lasting for $1.75 \mathrm{~h}$, and then, the water level remains still for $5.00 \mathrm{~h}$.

2. In the second test of reservoir water level fluctuations, the rising speed of reservoir water level is $18.00 \mathrm{~cm} / \mathrm{h}$, lasting for $2.50 \mathrm{~h}$, and then, the water level remains unchanged for $4.00 \mathrm{~h}$. After that, the water level of the reservoir starts to decline with falling speed of $30.00 \mathrm{~cm} / \mathrm{h}$, lasting for $1.50 \mathrm{~h}$, and then, the water level remains still for $5.00 \mathrm{~h}$.

3. Groundwater is added into the third test of reservoir water level fluctuations with other conditions the same as the second test. The groundwater level is applied at the interface between the groundwater level line and bedrock at the trailing edge of the landslide model, and the height of the groundwater level is calculated according to the geometric similarity ratio.

Table 2 Test scheme

\begin{tabular}{ccccc}
\hline & & Speed $(\mathrm{cm} / \mathrm{h})$ & Duration $(\mathrm{h})$ & Maintained time $(\mathrm{h})$ \\
\hline \multirow{4}{*}{ Without } & Rise & 6.43 & 7.00 & 4.00 \\
groundwater & Fall & 25.71 & 1.75 & 5.00 \\
\cline { 2 - 5 } & Rise & 18.00 & 2.50 & 4.00 \\
& Fall & 30.00 & 1.50 & 5.00 \\
\hline \multirow{2}{*}{ With groundwater } & Rise & 18.00 & 2.50 & 4.00 \\
& Fall & 30.00 & 1.50 & 5.00 \\
\hline
\end{tabular}




\section{Test results and analysis}

\subsection{Variation of pore water pressure}

The variation of pore water pressure caused by reservoir water level fluctuations is shown in Fig. 7. In the first test, the pore water pressure first decreases and then increases when reservoir water level initially rises. The rise of reservoir water level causes local cracks and expansion of soil volume at the leading edge of the sliding body. When the water level is held still, the max pore water pressure fluctuates due to the uneven landslide deformation caused by soak and softening. When reservoir water level falls, the pore water pressure decreases with rate slower than decreasing rate of reservoir water level. When reservoir water level remains unchanged, the pore water pressure continues to decrease, indicating that during the rapid fall of reservoir water level, the dissipation of pore water pressure in the sliding body is slow, forming seepage pressure which points to the outside of the sliding body surface. The occurrence of seepage pressure is an important factor inducing landslides during the fall of reservoir water level. After the first round of rise and fall of reservoir water level, tensile cracks appear on the surface of the sliding body, as shown in Fig. 10(a).

After the first test of reservoir water level fluctuations, the water content in the landslide is high, hence the pore water pressures $\mathrm{p}_{1}$ and $\mathrm{p}_{2}$ respond quickly with the rise of reservoir water level. The peak pore water pressures $\mathrm{p}_{1}$ and $\mathrm{p}_{2}$ during the second rise of reservoir water level are slightly lower than those during the first rise of reservoir water level, mainly due to deformation and tensile cracks occurred after the first test of reservoir water level fluctuations. The difference between the peak pore water pressures at point $p_{3}$ during the first and second rises of reservoir water level is not large because of small deformation. After the second test of reservoir water level fluctuations, new tensile cracks appear on the sliding body, as shown in Fig. 10 (b).

Groundwater is applied and remains still during the third round of fluctuations of reservoir water level. When reservoir water level rises, it reaches the pre-specified value about 30 minutes earlier compared with the second test without groundwater; when reservoir water level falls, it reaches the pre-specified value approximately 30 minutes later compared with tests without groundwater. It is shown that groundwater forms a basically stable seepage in the landslide. Influenced by groundwater, the pore water pressure $\mathrm{p}_{1}$ increases the fastest among the three points $\mathrm{p}_{1}, \mathrm{p}_{2}$, and $\mathrm{p}_{3}$. Due to the large slope of the bedrock surface at $\mathrm{p}_{2}$ and $\mathrm{p}_{3}$, the pore water pressure sensors at $\mathrm{p}_{2}$ and $\mathrm{p}_{3}$ are liable to slide down along the bedrock surface when the landslide deforms, causing slow increase of the pore water pressure. 


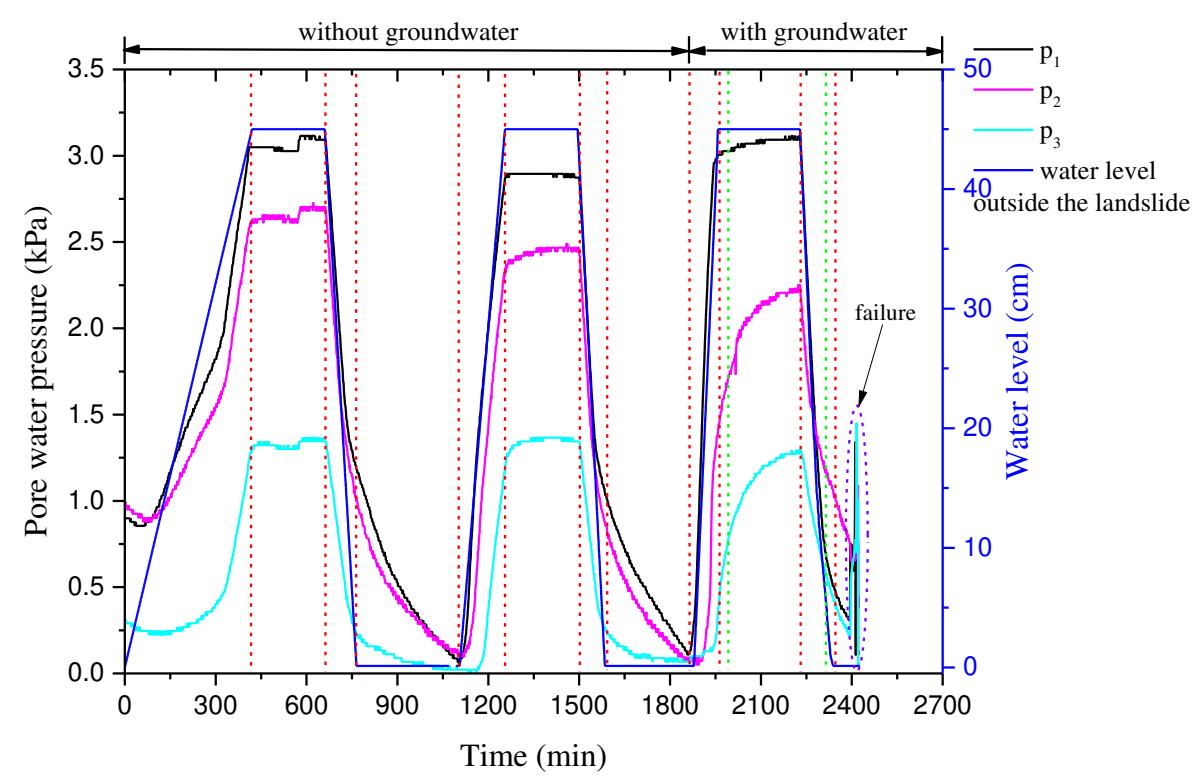

Fig. 7 Variation of pore water pressure under fluctuations of reservoir water level

After the third fall of reservoir water level, the landslide is triggered by the undissipated groundwater inside the sliding body. The variation of pore water pressure during the failure is shown in Fig. 8. The duration of the failure process is about $13 \mathrm{~min}$ (from 2411 to $2423 \mathrm{~min}$ ), and the fluctuation of pore water pressure occurred at $\mathrm{p}_{1}$ first, then at $\mathrm{p}_{2}$ and $\mathrm{p}_{3}$. After the landslide failure, pore water pressures at these three measuring points became stable.

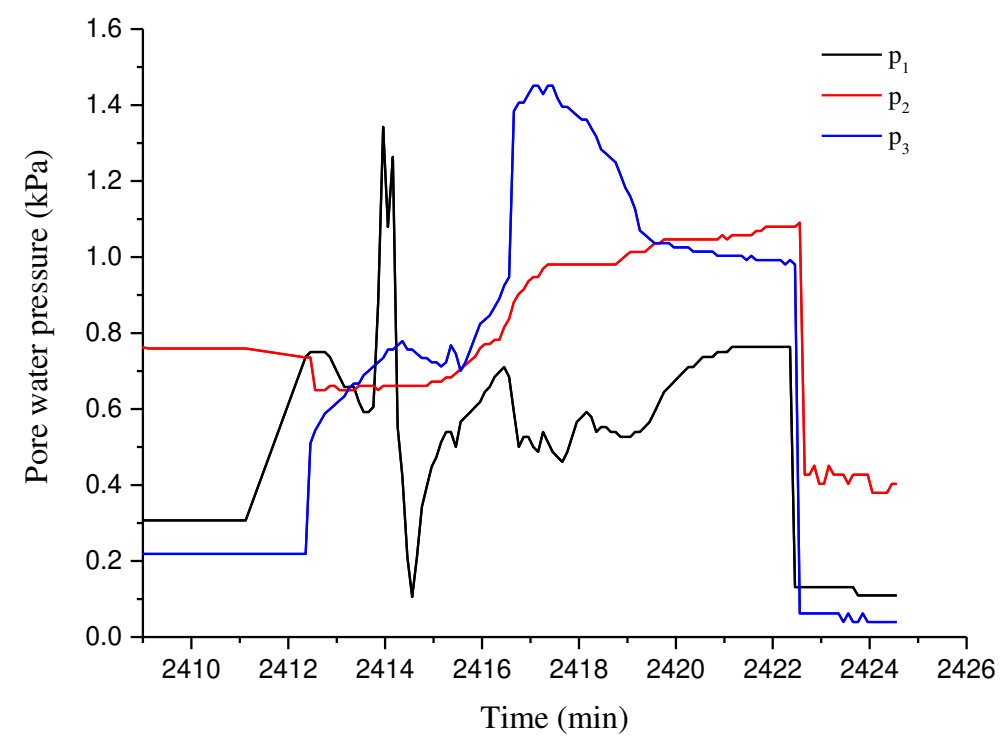

Fig. 8 Variation of pore water pressure during landslide failure

By comparing the first and second tests, it can be seen that the larger the rising speed of reservoir water level, the slower the pore water pressure increases; the larger the falling speed of the reservoir water level, the slower the pore water pressure dissipates in the sliding body. By comparing the second and third tests, it can be seen that the dynamic seepage pressure due to fall of reservoir water level and groundwater are the main reasons inducing landslide.

\subsection{Landslide cumulative displacement and failure characteristics}

Variation of cumulative displacement with fluctuations of reservoir water level is presented in 
Fig. 9. In general, the closer the monitoring points to the foot of the sliding body, the greater the landslide displacement. Compared with the second and third reservoir water level rising, the first reservoir water level rising has the most remarkable impact on the landslide displacement, consistent with the conclusions of He et al. ${ }^{[26]}$ The landslide displacement appears as slow creep during the rise and steady periods of the reservoir water level. When the reservoir water level falls rapidly at speed of $25.71 \mathrm{~cm} / \mathrm{h}$, the displacement of D1 and D2 increase gradually, and change of displacement accelerates. Since point D3 is far away from the reservoir water level, the displacement of D3 is slower than those at D1 and D2. The failure characteristics of the landslide after the first test are shown in Fig. 10 (a). The main failure feature is three tensile cracks in the landslide.

When the reservoir water level falls at the speed of $30 \mathrm{~cm} / \mathrm{h}$, the landslide displacement law is similar to the first test. The failure characteristics after the second test are presented in Fig. 10 (b), showing that the tensile cracks develop further. When the groundwater is applied for the third test, the slip surface became gradually saturated, and the landslide displacement continues to increase. The landslide failure process is presented in Fig. 11. It can be concluded that the partial disintegration occurs initially at the leading edge of the sliding body, and then the front portion of the sliding body slides along the through cracks.

The landslide displacement during the three tests shows that the groundwater has an important influence on the stability of landslide. After groundwater is applied, the change of landslide displacement during the rise of reservoir water level is huger, and the displacement keeps increasing during the falling process of reservoir water level.

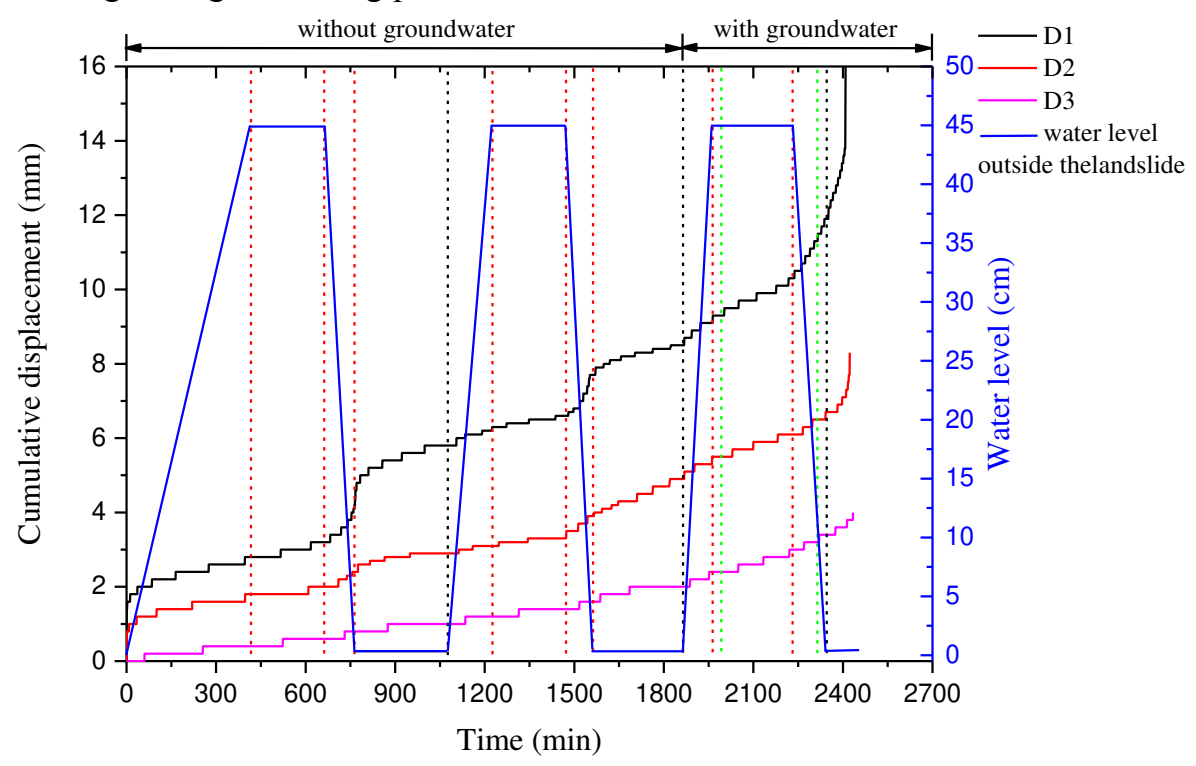

Fig. 9 Variation of cumulative displacement under reservoir water level fluctuations 


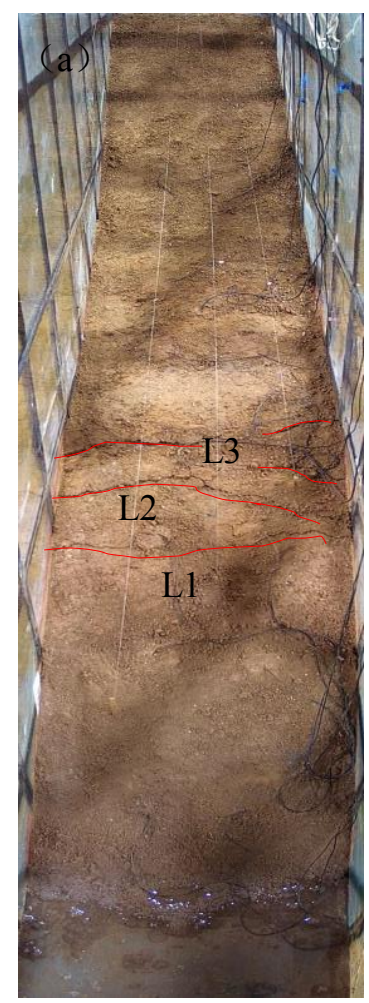

(a)

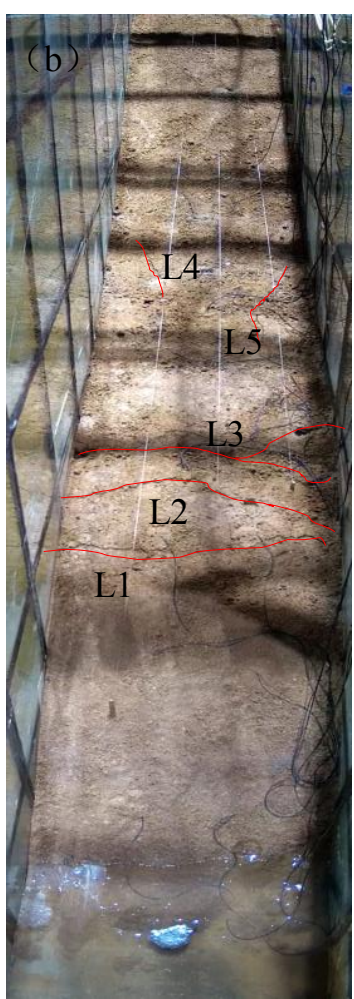

(b)

Fig. 10 Failure characteristics of landslides without groundwater, (a) the first test, (b) the second test

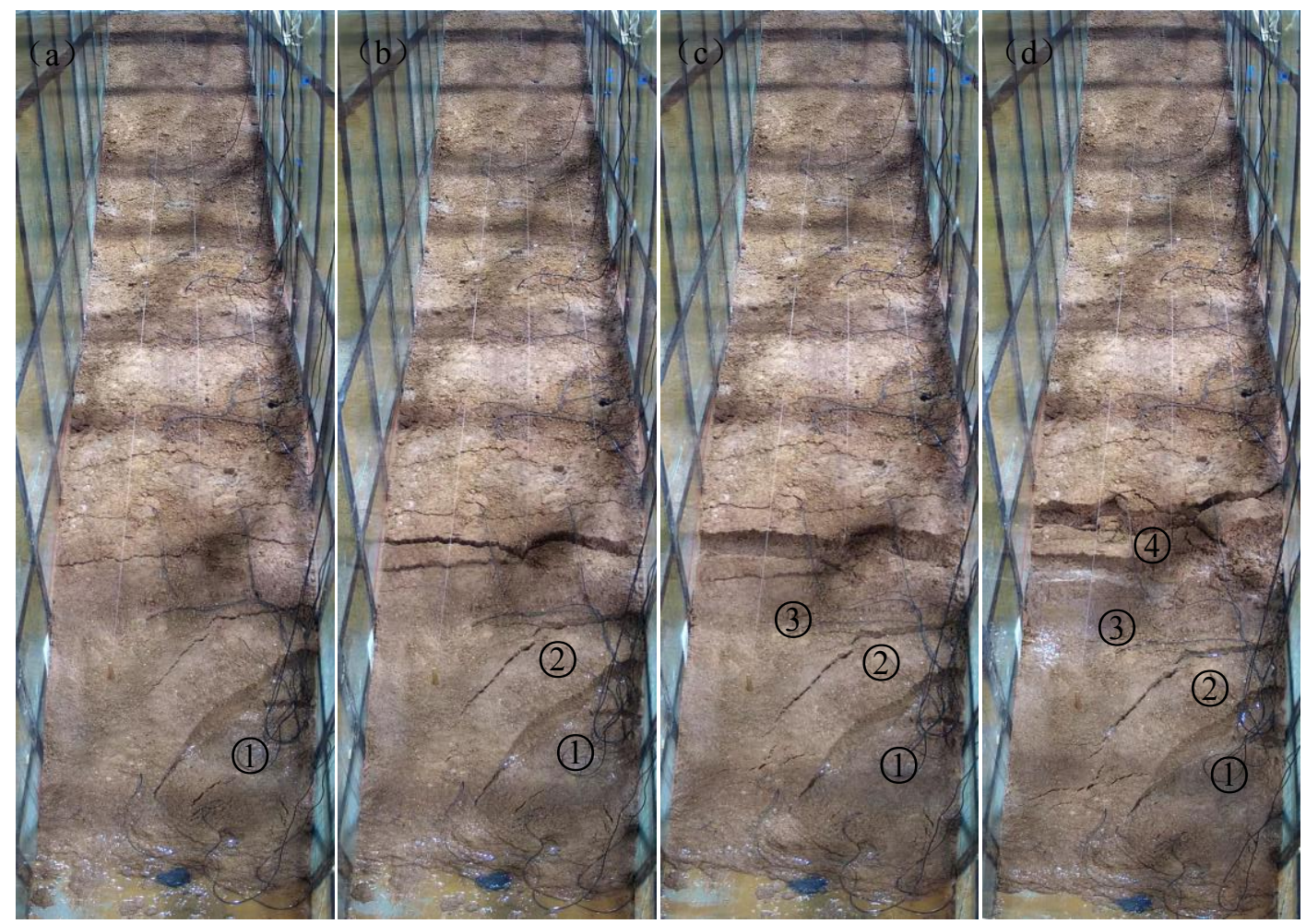

Fig. 11 Failure characteristics of landslides with groundwater 


\section{Discussions}

\subsection{Groundwater level inside the landslide and reservoir water level}

Reservoir water level fluctuations will inevitably lead to changes of the groundwater level inside the landslide. The higher the groundwater level, the greater the sliding force of the landslide. Therefore, analyzing the relationship between the groundwater level inside the landslide and the reservoir water level is very important to understand the mechanism of the environmental landslide disaster caused by fluctuations of reservoir water level ${ }^{[27]}$.

According to variation of landslide displacement with the reservoir water level fluctuation, changing rate of landslide displacement is relatively low during the rise process of reservoir water level, while changing rate of landslide displacement increases dramatically during the falling process of reservoir water level. Therefore, it is necessary to study the relationship between groundwater level inside the landslide and reservoir water level during the process of reservoir level falling.

Zheng et al. ${ }^{[28]}$ (2004) proposed an analytic solution to calculate the groundwater under uniform drawdown conditions:

$$
h_{x, t}= \begin{cases}h_{0,0}-v t\left(0.1091 \lambda^{4}-0.7501 \lambda^{3}+1.9283 \lambda^{2}-2.2319 \lambda+1\right) & (0 \leq \lambda<2) \\ h_{0,0} & (\lambda \geq 2)\end{cases}
$$

where $h_{x, t}$ is the hydraulic head at the location $x$ ( $x$ is the horizontal distance to the intersection of the landslide surface and initial water level), at time $t(t$ is the elapsed time since the start of the fall of reservoir water level); $h_{0,0}$ is the reservoir water level before falling; $v(\mathrm{~m} / \mathrm{d})$ is the falling speed of reservoir water level; $\lambda=\frac{x}{2} \sqrt{\frac{\mu}{K h_{\mathrm{m}} t}}$ (where $K(\mathrm{~m} / \mathrm{d})$ is the permeability coefficient of the sliding body; $\mu$ is the specific yield of the sliding body mass; $h_{\mathrm{m}}(\mathrm{m})$ is the average thickness of the water bearing layer; $h_{\mathrm{m}}=0.301 \mathrm{~m}$ is used in this paper).

For domestic and international test materials of gravel soil and cohesive soil, an empirical formula for the specific yield of the sliding body mass is provided by $\mathrm{Mao}^{[29]}$ as follow:

$$
\mu=1.137 n(0.0001175)^{0.607^{\left(6+1 \log _{10}{ }^{k}\right)}}
$$

where $n$ is the porosity of the sliding body of the model landslide; $n=0.3038$ is used in this paper; $k(\mathrm{~cm} / \mathrm{s})$ is the permeability coefficient of the sliding body of the model landslide; $\mu=$ 0.0342 can be obtained from equation (2).

According to equation (1), the groundwater level in the landslide after the decline of the reservoir water level is shown in Fig. 12. $v_{1}$ and $v_{2}$ are the falling speed of reservoir water level in our study; $v_{0}$ is used as a comparison to illustrate the impact of the falling speed of the reservoir water level on the groundwater level in the landslide. As shown in Fig. 12, the faster falling speed of reservoir water level, the higher the groundwater level is. And the falling speed of reservoir water level has a great influence on the height of the groundwater level. When the falling speed of reservoir water level is $6.43 \mathrm{~cm} / \mathrm{h}$, the groundwater level is as low as $6.98 \mathrm{~cm}$ at location of $x=0.2$ $\mathrm{m}$. However, the groundwater level is $13.98 \mathrm{~cm}$ at location of $x=0.2 \mathrm{~m}$ with the falling speed of reservoir water level at $30.00 \mathrm{~cm} / \mathrm{h}$. 


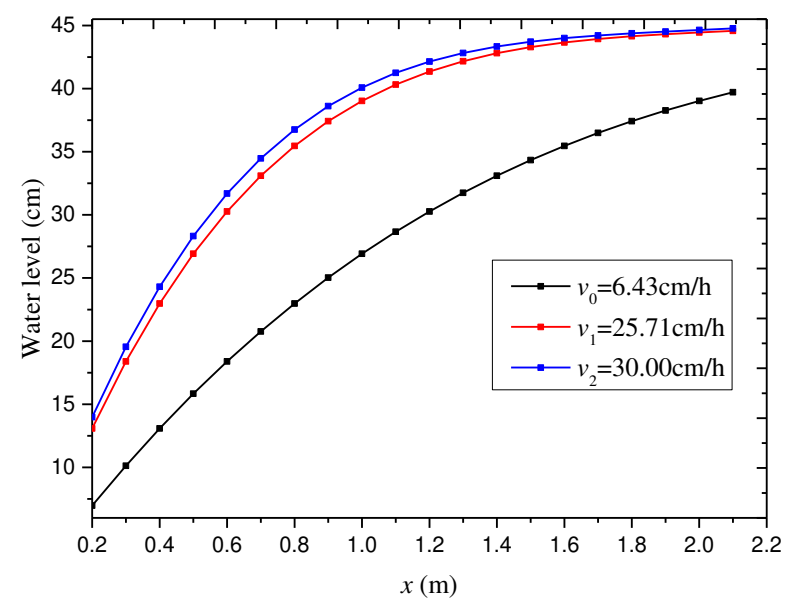

Fig. 12 Groundwater level of different fall speed after the fall of reservoir water level

The variation of groundwater level in the landslide calculated by equation (1) and reservoir water level is shown in Fig. 13. As can be seen, the groundwater level falls faster than the water level in the reservoir. Forced by the gravity, the groundwater remaining in the sliding body forms the seepage pressure pointing out of the sliding body. The higher groundwater level inside the landslide, the greater the seepage pressure. The seepage pressure is considered as one of the main factors inducing landslide ${ }^{[30-31]}$.
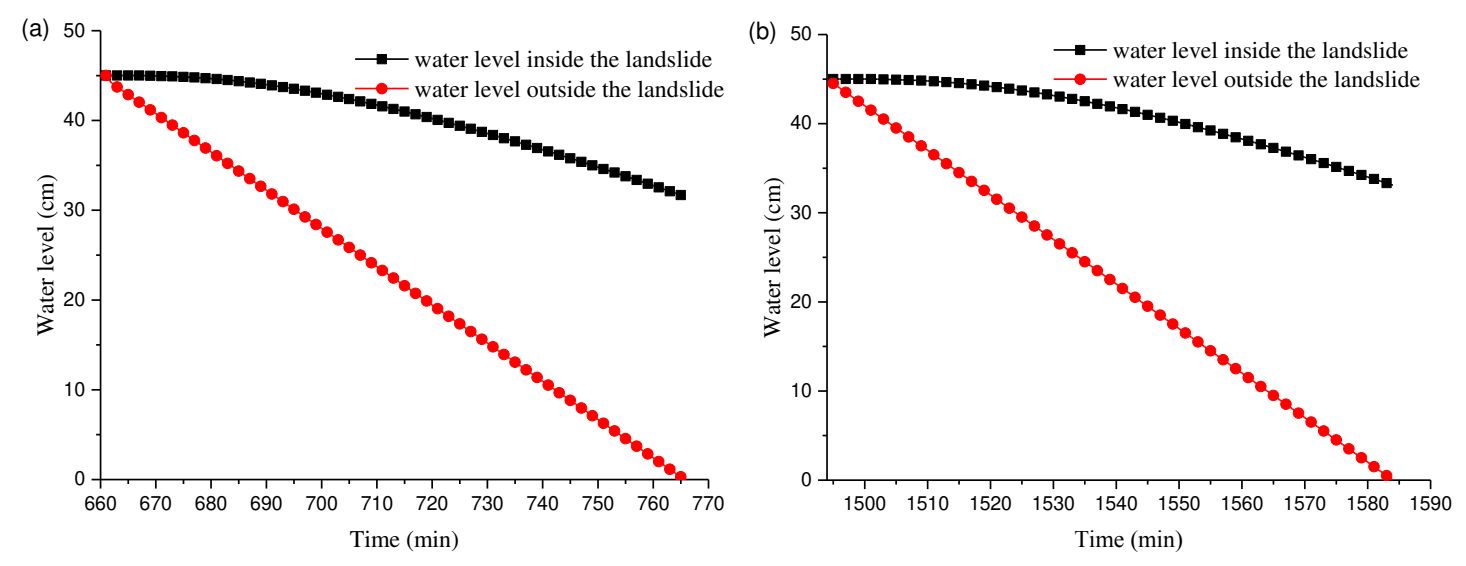

Fig. 13 Variations of groundwater level inside the landslide and reservoir water level with different falling speeds of reservoir water level, (a) $v_{1}=25.71 \mathrm{~cm} / \mathrm{h}$, (b) $v_{2}=30.00 \mathrm{~cm} / \mathrm{h}$

\subsection{Groundwater level and landslide displacement}

Pinyol et al. ${ }^{[32]}$ believed that landslide displacement is associated with the reservoir water level drawdown. After decreasing of reservoir water level, the groundwater level in the landslide is higher than the reservoir water level. The relationship between the difference of water level difference $(\Delta \mathrm{h})$ and the landslide displacement should be studied. The groundwater level and reservoir water level at measuring point D1 are considered in this study. Variation and fitting curves of landslide displacement and the water level difference with different falling speeds are shown in Fig. 14. With water level difference increasing, the landslide displacement gradually increases and exhibits a positive correlation with water level difference $(\Delta \mathrm{h})$. The changing law of displacement after reservoir water level drawdown in the physical model test agrees with the outcomes of the studies conducted by $\mathrm{Gu}$ et al. ${ }^{[33]}$ and $\mathrm{Wu}$ et al. ${ }^{[34]}$. Therefore, attentions should be paid on water level difference between groundwater level inside the landslide and the reservoir 
water level during the falling process of reservoir water level.
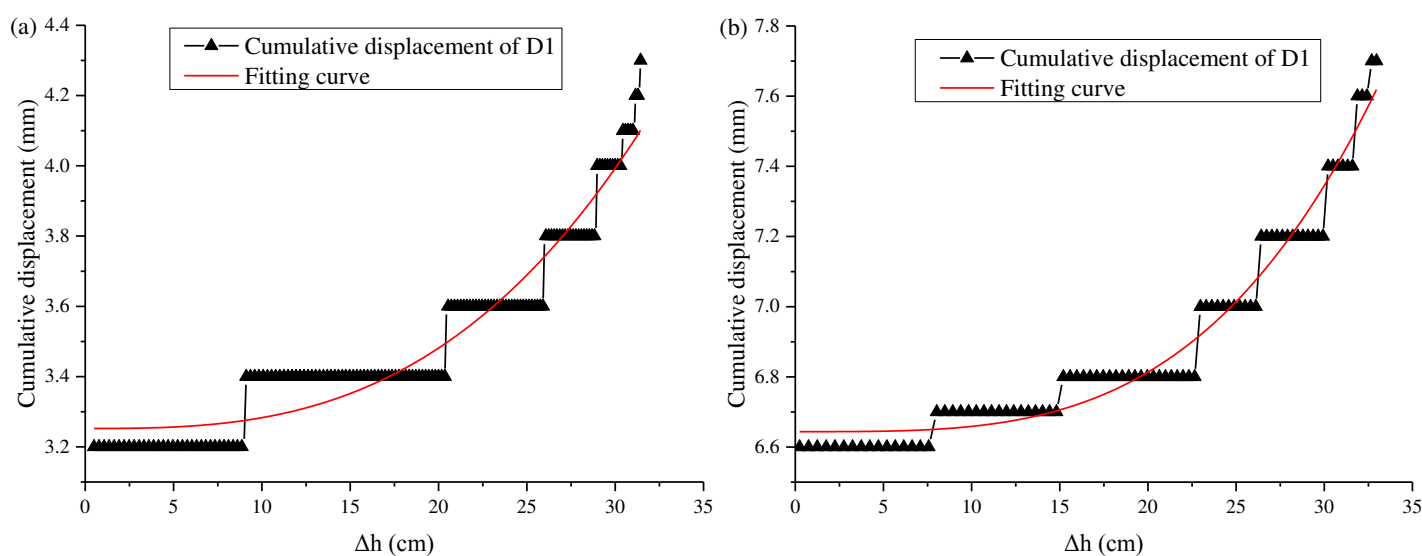

Fig. 14 Variation of landslide displacement with the difference of water level between inside the landslide and the reservoir water level under different falling speed (a) $v_{1}=25.71 \mathrm{~cm} / \mathrm{h}$, (b)

$$
v_{2}=30.00 \mathrm{~cm} / \mathrm{h}
$$

According to the variation curve of landslide displacement and water level difference, a power function is selected to describe the relationship:

$$
D=a+b \Delta h^{c}
$$

where $D(\mathrm{~mm})$ is the landslide displacement at measuring point $\mathrm{D} 1 ; a, b$, and $c$ are fitting parameters.

The fitting results are shown in Fig. 14 and summarized in Table 3. The correlation coefficient is very high, with a minimum value of 0.935 . Therefore, the power function is suitable to describe the variation of the landslide displacement with groundwater level difference.

Table 3 Fitting parameters

\begin{tabular}{ccccc}
\hline $\begin{array}{c}\text { Falling speed of } \\
\text { reservoir water level }\end{array}$ & $a$ & $b$ & $c$ & $R^{2}$ \\
\hline$v_{1}=25.71 \mathrm{~cm} / \mathrm{h}$ & 3.252 & $3.897 \times 10^{-5}$ & 2.897 & 0.935 \\
$v_{2}=30.00 \mathrm{~cm} / \mathrm{h}$ & 6.644 & $4.737 \times 10^{-6}$ & 3.500 & 0.963 \\
\hline
\end{tabular}

\subsection{Landslide displacement in physical model tests and prototype}

Despite large number of researches on deformation laws of landslide using physical model tests ${ }^{[23-24,26]}$, most of researches did not involve relationship between model test and prototype due to lack of field monitoring displacement data. In this paper, displacements of the physical model test, directly calculated by geometric similarity ratio, was evaluated against the field monitoring data during rising process of the reservoir water level. As shown in Fig. 15, the changing trend of displacement acquired by physical model test is generally consistent with that from prototype monitoring data. 


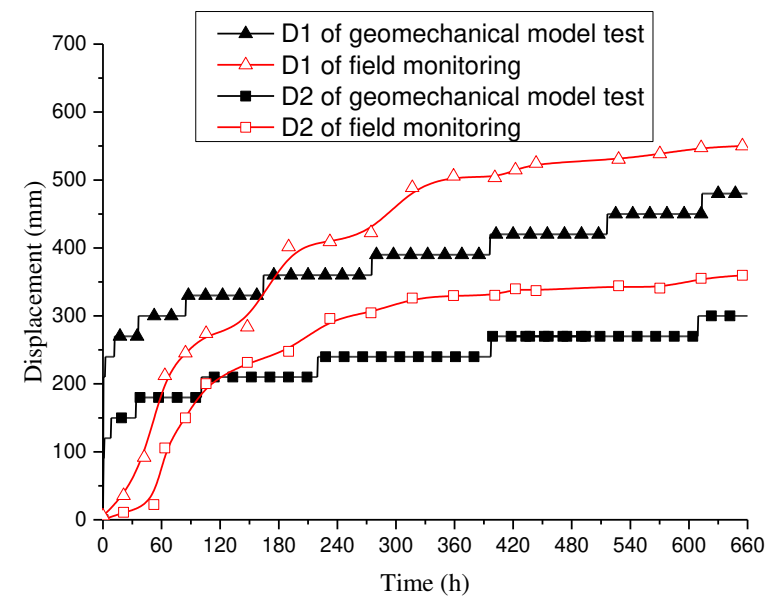

Fig. 15 Comparison between the physical test displacement and field monitoring displacement

during the reservoir water level rise

According to Luo et al. ${ }^{[35]}$, model test cannot completely satisfy the similarity relationship due to the physical and mechanical parameters of the similar materials, thus aberration can be found between displacements of model test and the prototype. In our study, the physical and mechanical parameters of the similar materials consider the density, angle of internal friction, cohesion, permeability coefficient, the similarity of the deformation modulus, Poisson's ratio and other factors haven't been considered by former researches. In addition, the boundary condition between model and prototype landslides is different, which inevitably causing difference between landslide displacements acquired by two methods. However, the results of model test are meaningful for scheduling reservoir water level. Both the results of prototype and model tests show that the displacement of front edge of landslide during the reservoir water level fluctuations deserves more attentions.

\section{Conclusions}

Based on the similarity theory, a physical model was established, and landslide test induced by reservoir water level fluctuations was conducted. Then, change of landslide displacement with variation of groundwater level and the mechanism of landslide caused by reservoir water level fluctuations were studied. Main conclusions are as follows:

1. The change of pore water pressure in the landslide is consistent with that of reservoir water level: the pore water pressure increases with the rise of reservoir water level and decreases with the fall of reservoir water level. During the falling process of reservoir water level, the decrease of pore water pressure lags behind the fall of reservoir water level, causing seepage pressure pointing out of the sliding body surface. The seepage increases changing rate of landslide displacement and evenly leads to landslide instability.

2. The rising or falling speed of reservoir water level affects changing rate of the landslide displacement. The more rapid the rising or falling speed of the reservoir water level, the higher the rate of change of landslide displacement.

3. The landslide displacement has a positive correlation with the water level difference between groundwater level inside the landslide and the reservoir water level $(\Delta \mathrm{h})$. A power function model is used to describe the variation of the landslide displacement with water level difference during the falling process of reservoir water level.

4. The landslide firstly fails in the front of the sliding body under effects of groundwater and 
reservoir water level fluctuations. The sliding body then suffered overall damage near the design reservoir water level, and the damage is characterized by traction landslide.

\section{Acknowledgements}

Financial supports from the National Key R\&D Program of China (2017YFC1501100), Postgraduate Research \& Practice Innovation Program of Jiangsu Province (Grant No. SJKY19_0422), the National Natural Science Foundation of China (Grant No. 11772116), and the Qinglan project are gratefully acknowledged.

\section{Declarations}

The authors declared that they have no conflicts of interest to this work.

\section{References}

[1] Müller, L. (1964). The rock slide in the Vajont Valley. Rock Mechanics and Engineering Geology, 2, 148-212.

[2] Hendron, A. J., \& Patton, F. D. (1985). The Vaiont slide: a geotechnical analysis based on new geologic observations of the failure surface (No. 5 FINAL REPO).

[3] Strauhal, T., Loew, S., Holzmann, M., et al. (2016). Detailed hydrogeological analysis of a deep-seated rockslide at the Gepatsch reservoir (Klasgarten, Austria). Hydrogeology journal, 24(2), 349-371.

[4] Wang, F. W., Zhang, Y. M., Huo, Z. T., et al. (2004). The July 14, 2003 Qianjiangping landslide, three gorges reservoir, China. Landslides, 1(2), 157-162.

[5] Dai, F. C., Deng, J. H., Tham, L. G., et al. (2004). A large landslide in Zigui County, Three Gorges area. Canadian Geotechnical Journal, 41(6), 1233-1240.

[6] Sherard, J. L. (1987). Lessons from the teton dam failure. Engineering Geology, 24(1-4), 239-256.

[7] Serafim, J. L. (1987). Malpasset dam discussion - remembrances of failures of dams. Engineering Geology, 24(1), 355-366.

[8] Jones, F. O., Embody, D. R., Peterson, W. L., et al. (1961). Landslides along the columbia river valley, northeastern washington, with a section on seismic surveys (No. 367). US Government Printing Office.

[9] Nakamura, K. (1990). On reservoir landslide. Bulletin of Soil and Water Conservation, 10(1), 53-64. (in Chinese)

[10] Fujita, H. (1977). Influence of water level fluctuations in a reservoir on slope stability. Bulletin of the International Association of Engineering Geology, 16(1), 170-173.

[11] Tang, H., Li, C., Hu, X., et al. (2015). Deformation response of the Huangtupo landslide to rainfall and the changing levels of the Three Gorges Reservoir. Bulletin of Engineering Geology and the Environment, 74(3), 933-942.

[12] Dumperth, C., Rohn, J., Fleer, A., et al. (2016). Local-scale assessment of the displacement pattern of a densely populated landslide, utilizing finite element software and terrestrial radar interferometry: a case study on Huangtupo landslide (PR China). Environmental Earth Sciences, 75(10), 880. doi:10.1007/s12665-016-5475-y 
[13] Zhang, S., Pei, X., Wang, S., et al. (2019). Centrifuge model testing of a loess landslide induced by rising groundwater in Northwest China. Engineering geology, 259, 1-14. doi:10.1016/j.enggeo.2019.105170

[14] Shi, J. S., Wu, L. Z., Wu, S. R., et al. (2016). Analysis of the causes of large-scale loess landslides in Baoji, China. Geomorphology, 264, 109-117. doi:10.1016/j.geomorph.2016.04.013

[15] Yan, L., Xu, W., Wang, H., et al. (2019). Drainage controls on the Donglingxing landslide (China) induced by rainfall and fluctuation in reservoir water levels. Landslides, 16(8), 1583-1593.

[16] Yu, J., Wang, R. B., Zhang, J. C., et al. (2017). Deformational characteristics of Donglinxin slope induced by reservoir fluctuation and rainfall. Current Science, 113(6), 1159-1166. 6

[17] Zhao, Y., Li, Y., Zhang, L., et al. (2016). Groundwater level prediction of landslide based on classification and regression tree. Geodesy and Geodynamics, 7(5), 348-355. doi:10.1016/j.geog.2016.07.005

[18] Wang, J., Xiang, W., \& Lu, N. (2014). Landsliding triggered by reservoir operation: a general conceptual model with a case study at Three Gorges Reservoir. Acta Geotechnica, 9(5), 771-788

[19] Stark, T. D., Jafari, N. H., Leopold, A. L., et al. (2014). Soil compressibility in transient unsaturated seepage analyses. Canadian Geotechnical Journal, 51(8), 858-868.

[20] Song, K., Yan, E., Zhang, G., et al. (2015). Effect of hydraulic properties of soil and fluctuation velocity of reservoir water on landslide stability. Environmental earth sciences, 74(6), 5319-5329.

[21] Alonso, E. E., \& Pinyol, N. M. (2016). Numerical analysis of rapid drawdown: Applications in real cases. Water Science and Engineering, 9(3), 175-182. doi:10.1016/j.wse.2016.11.003

[22] Jia, G. W., Zhan, T. L., Chen, Y. M., et al. (2009). Performance of a large-scale slope model subjected to rising and lowering water levels. Engineering Geology, 106(1-2), 92-103.

[23] Luo, X. Q., Sun, H., Tham, L. G., et al. (2010). Landslide model test system and its application on the study of Shiliushubao landslide in Three Gorges Reservoir area. Soils and Foundations, 50(2), 309-317.

[24] He, C., Hu, X., Tannant, D. D., et al. (2018). Response of a landslide to reservoir impoundment in model tests. Engineering geology, 247, 84-93.

[25] Wang, J. J., Zhang, H. P., Zhang, L., et al. (2012). Experimental study on heterogeneous slope responses to drawdown. Engineering geology, 147, 52-56.

[26] He, C. C., Hu, X. L., Xu, C., et al. (2020). Model test of the influence of cyclic water level fluctuations on a landslide. Journal of Mountain Science, 17(1), 191-202.

[27] Yan, Z. L., Wang, J. J., \& Chai, H. J. (2010). Influence of water level fluctuation on phreatic line in silty soil model slope. Engineering Geology, 113(1-4), 90-98.

[28] Zheng, Y. R., Shi, W. M., \& Kong, W. X. (2004). Calculation of seepage forces and phreatic surface under drawdown conditions. Chinese Journal of Rock Mechanics and Engineering, 23(18),3203-3210. doi:10.1097/00004836-200411000-00015

[29] Mao, Y. X. (2003). Seepage computation analysis and control. China Water \& Power Press.

[30] Cui, S. H., Pei, X. J., Wu, H. Y., et al. (2018). Centrifuge model test of an irrigation-induced loess landslide in the Heifangtai loess platform, Northwest China. Journal of Mountain Science, 15(1), 130-143. doi:10.1007/s11629-017-4490-0 
[31] Lane, P. A., \& Griffiths, D. V. (2000). Assessment of stability of slopes under drawdown conditions. Journal of geotechnical and geoenvironmental engineering, 126(5), 443-450.

[32] Pinyol, N. M., Alonso, E. E., Corominas, J., et al. (2012). Canelles landslide: modelling rapid drawdown and fast potential sliding. Landslides, 9(1), 33-51.

[33] Gu, D. M., Huang, D., Yang, W. D., et al. (2017). Understanding the triggering mechanism and possible kinematic evolution of a reactivated landslide in the Three Gorges Reservoir. Landslides, 14(6), 2073-2087.

[34] Wu, Q., Tang, H., Ma, X., et al. (2019). Identification of movement characteristics and causal factors of the Shuping landslide based on monitored displacements. Bulletin of Engineering Geology and the Environment, 78(3), 2093-2106.

[35] Luo, X. Q., Cheng, S. G., \& Niu, E. K. (2009). Research on aberration correction and application in landslide geomechanical model test. Chinese Journal of Rock Mechanics and Engineering, 28(z1), 3082-3088. doi:10.3321/j.issn:1000-6915.2009.z1.073 


\section{Figures}

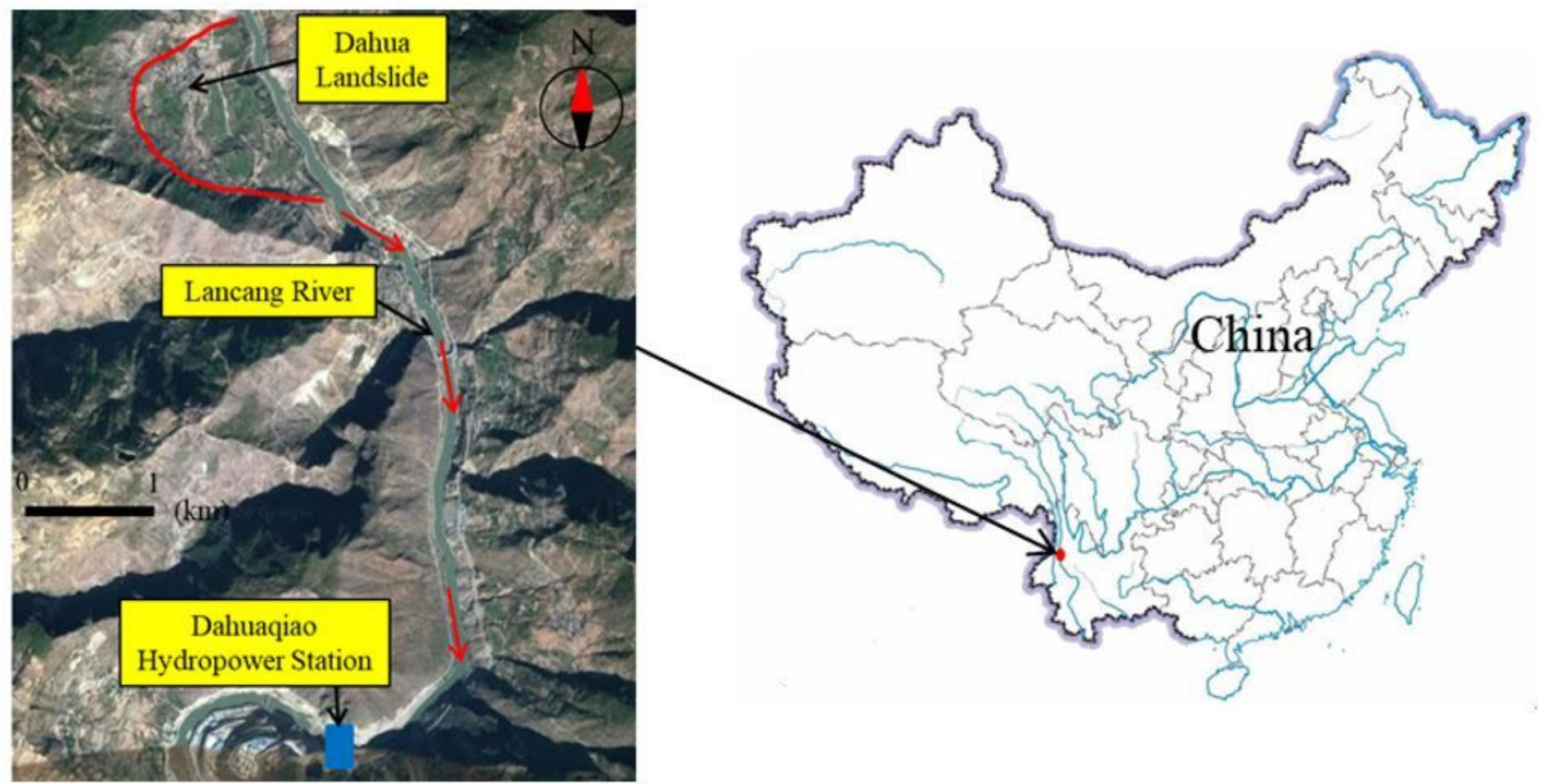

Figure 1

Site location of the Dahua landslide. Note: The designations employed and the presentation of the material on this map do not imply the expression of any opinion whatsoever on the part of Research Square concerning the legal status of any country, territory, city or area or of its authorities, or concerning the delimitation of its frontiers or boundaries. This map has been provided by the authors. 

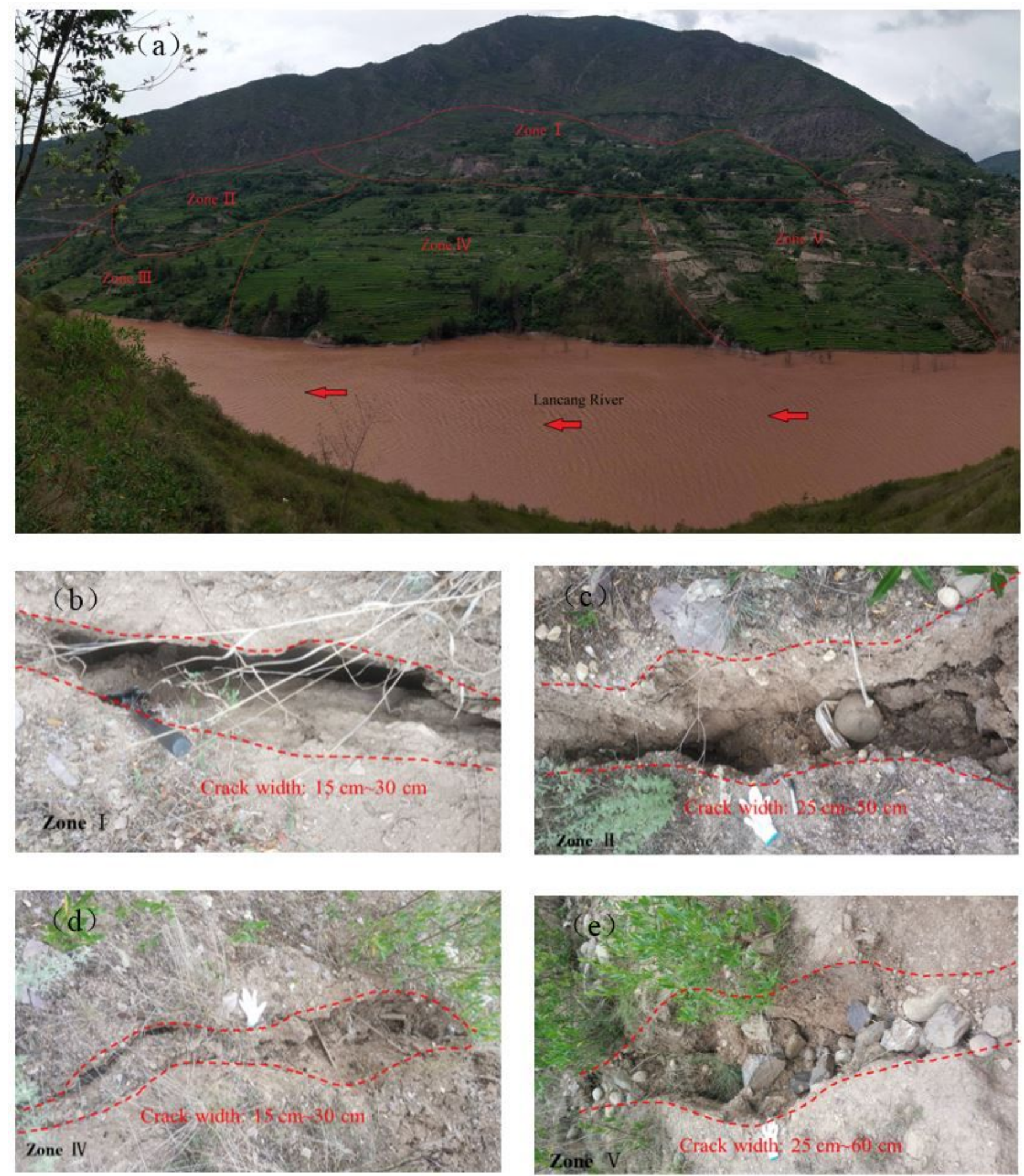

Figure 2

The topographic and geomorphic features of the Dahua landslide 


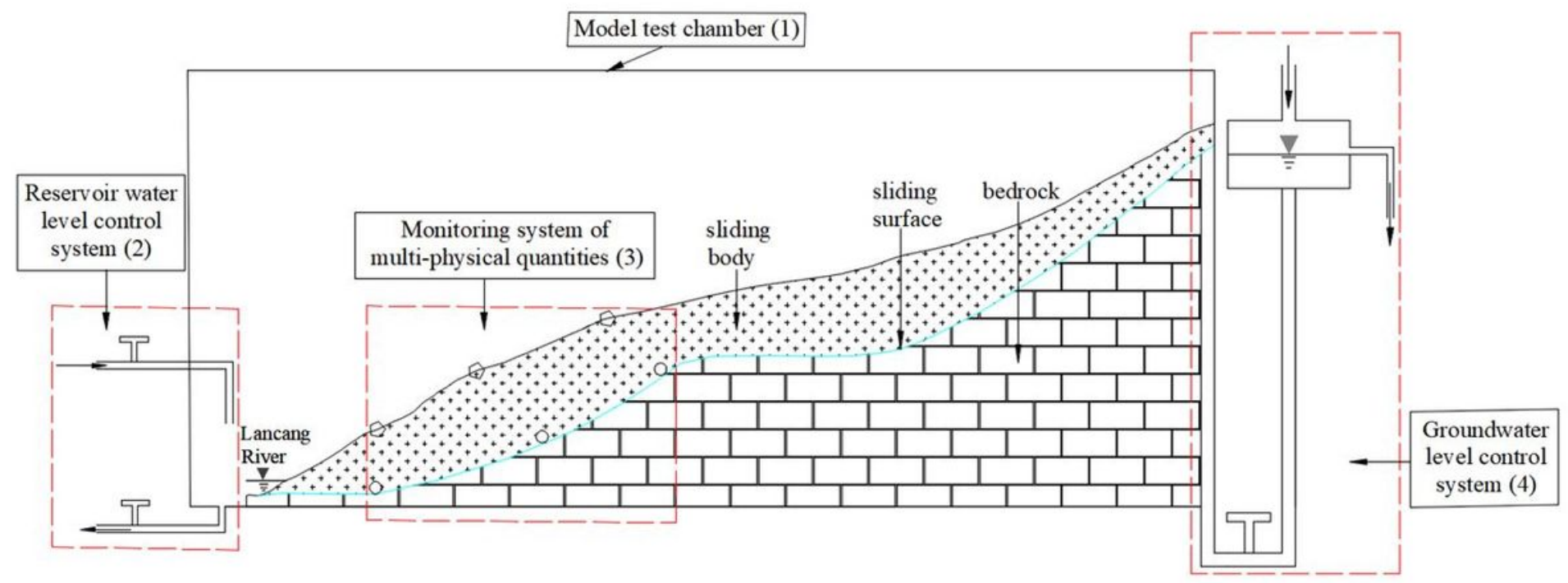

Figure 3

Schematic diagram of physical model test platform

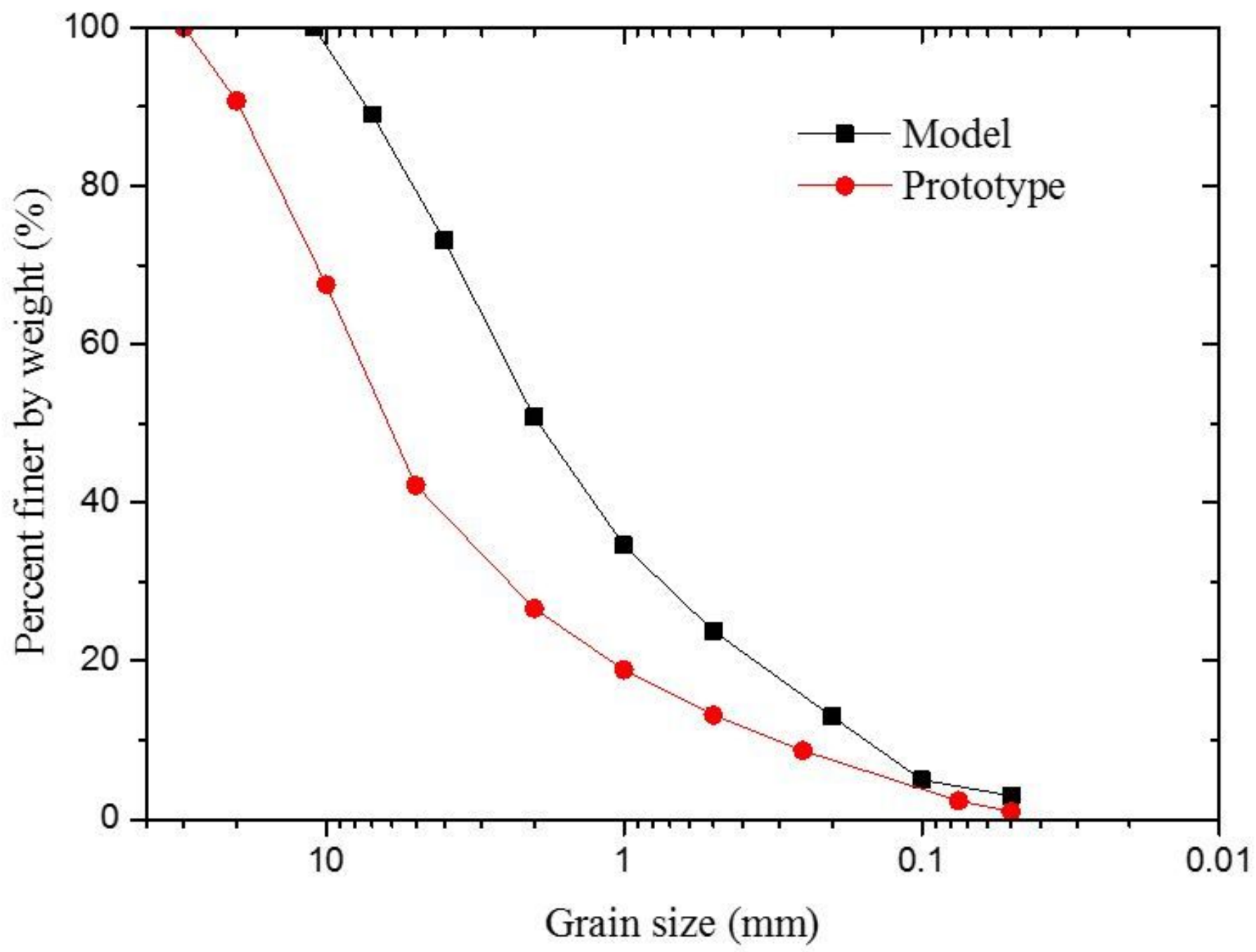

Figure 4 
Particle distribution curve of prototype and model landslide

Elevation

\section{Elevation}

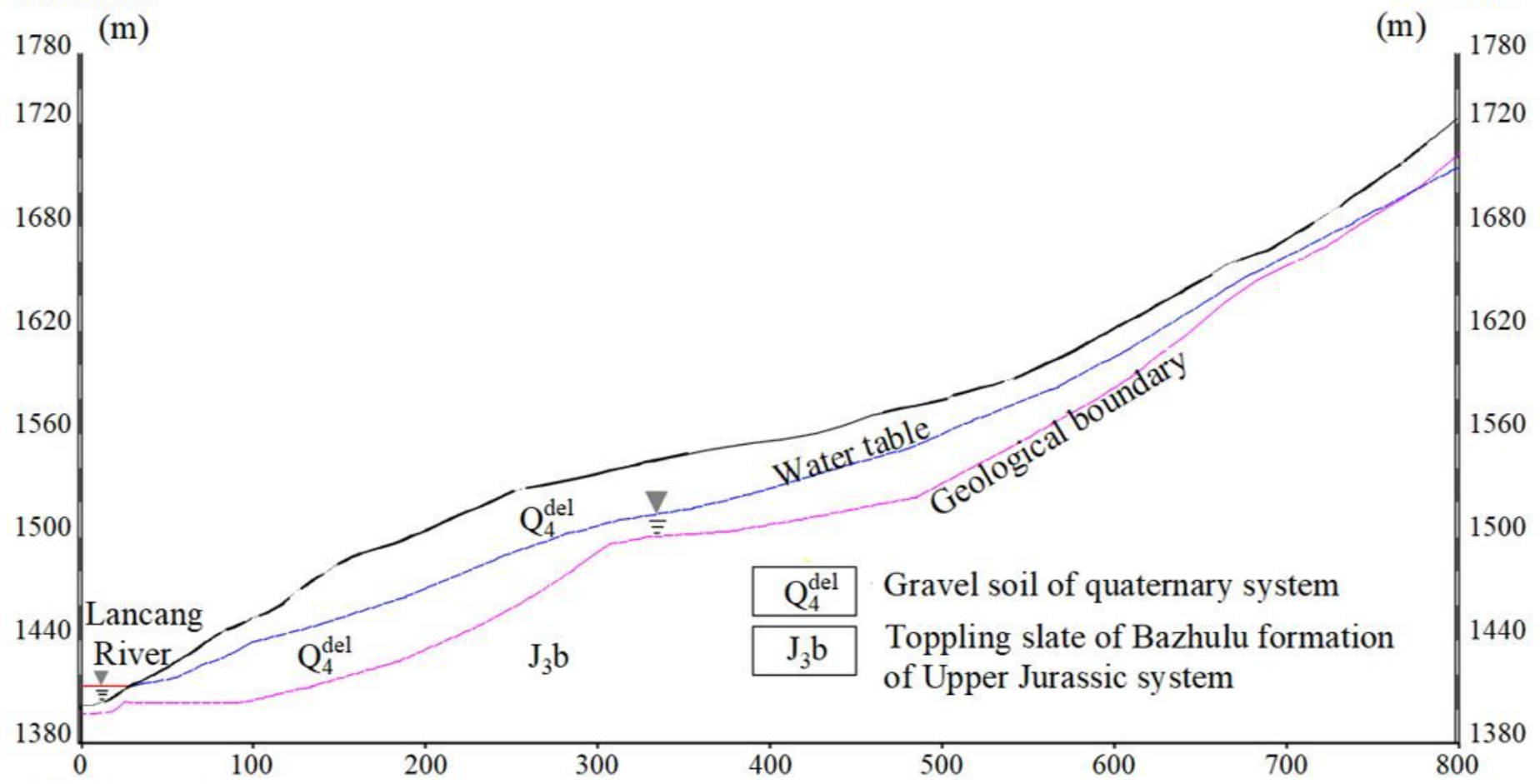

Distance (m)

\section{Figure 5}

Typical profile of Dahua landslide 


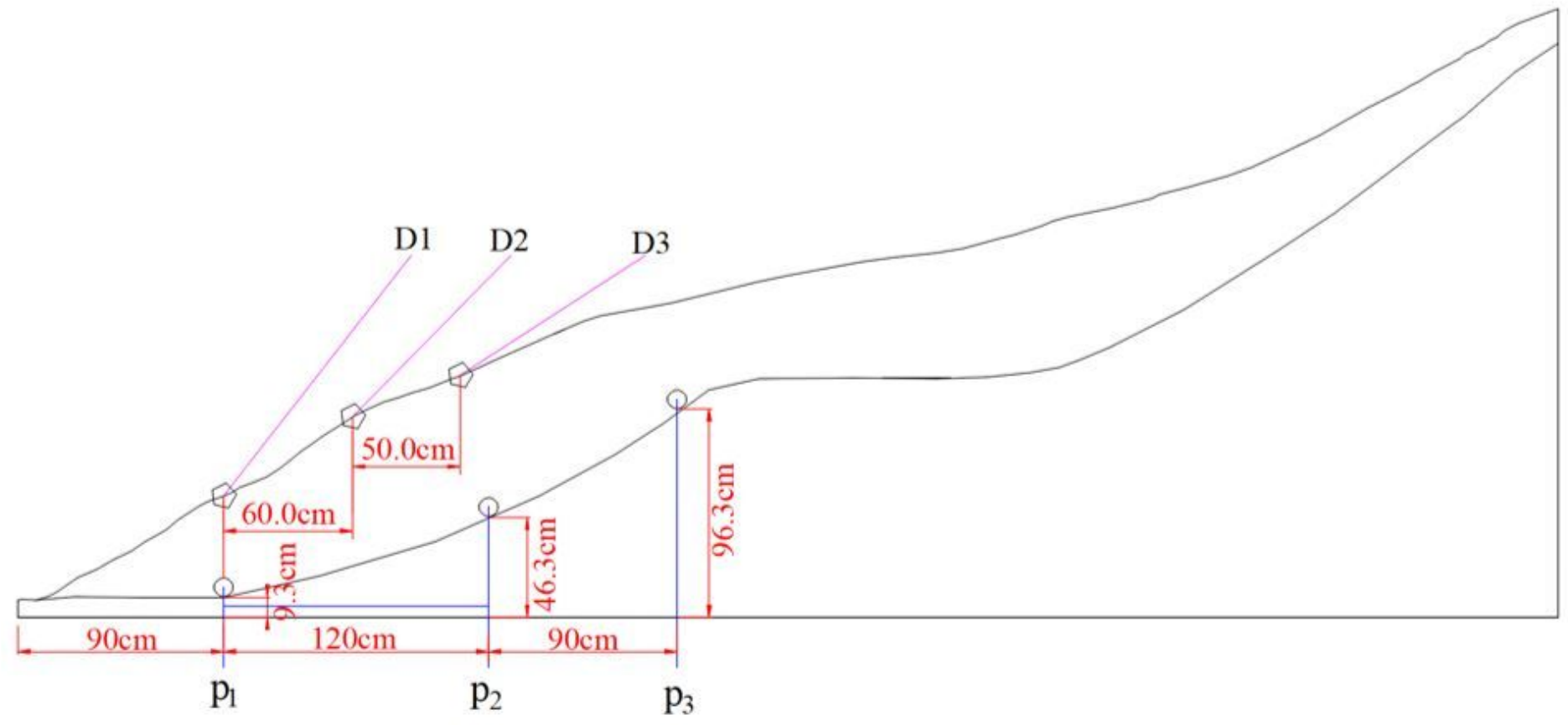

(a) Elevation arrangement of sensors

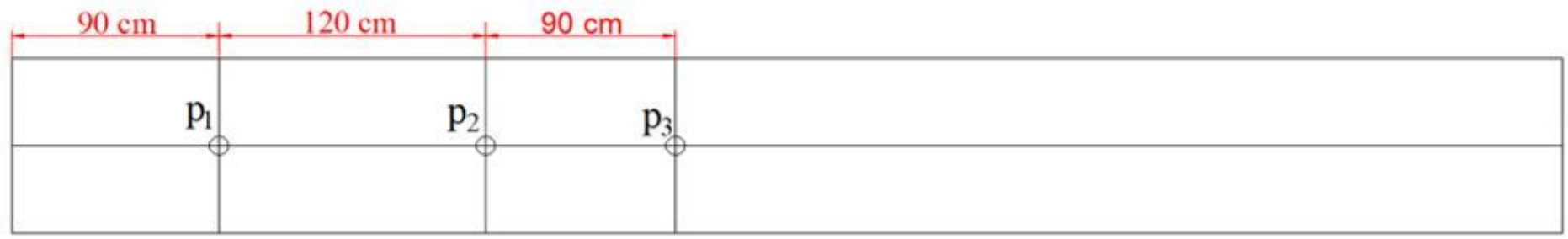

(b) Plane arrangement of sensors for sliding surface

Figure 6

Arrangement of instruments in the physical model 


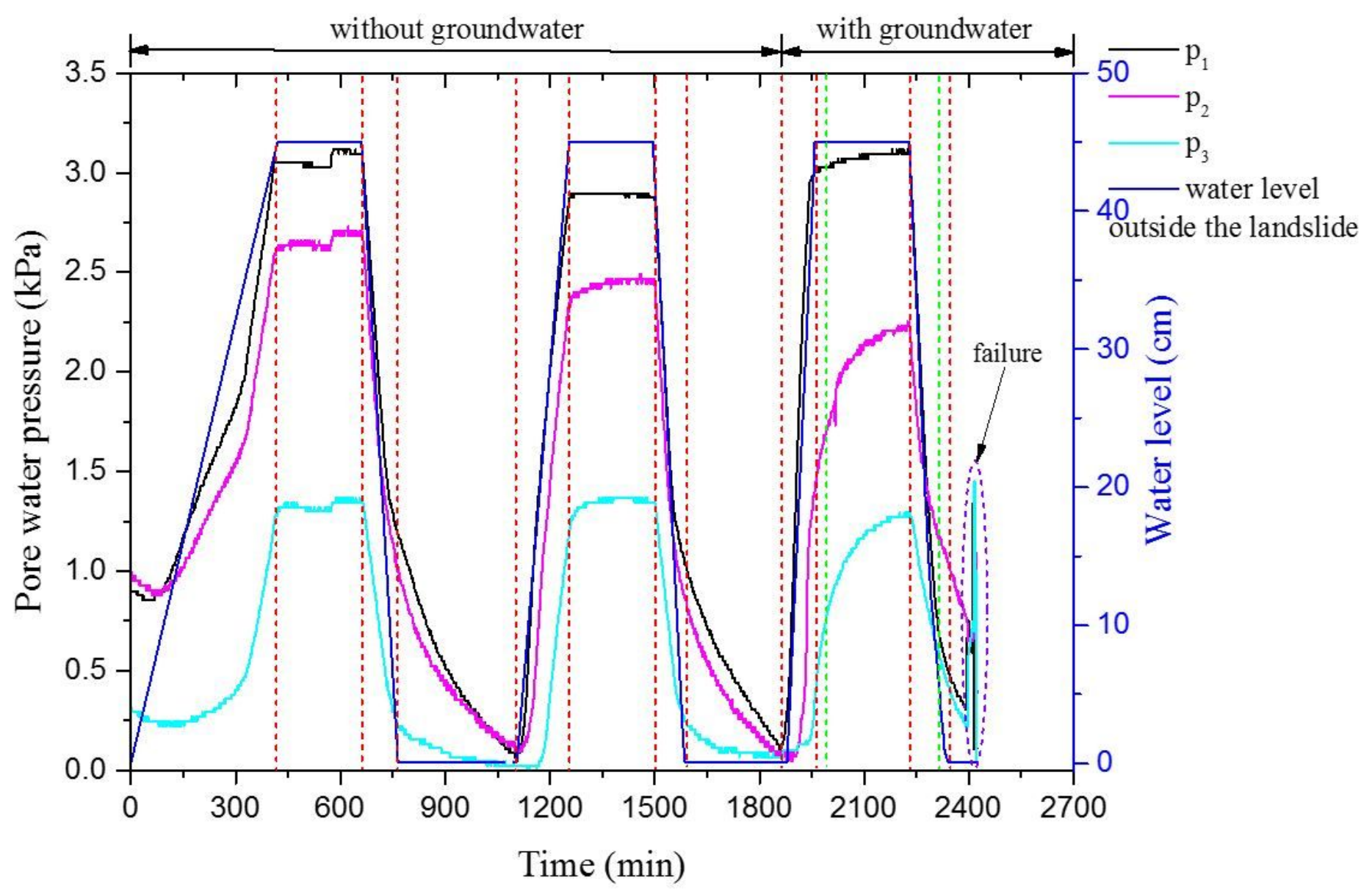

Figure 7

Variation of pore water pressure under fluctuations of reservoir water level 


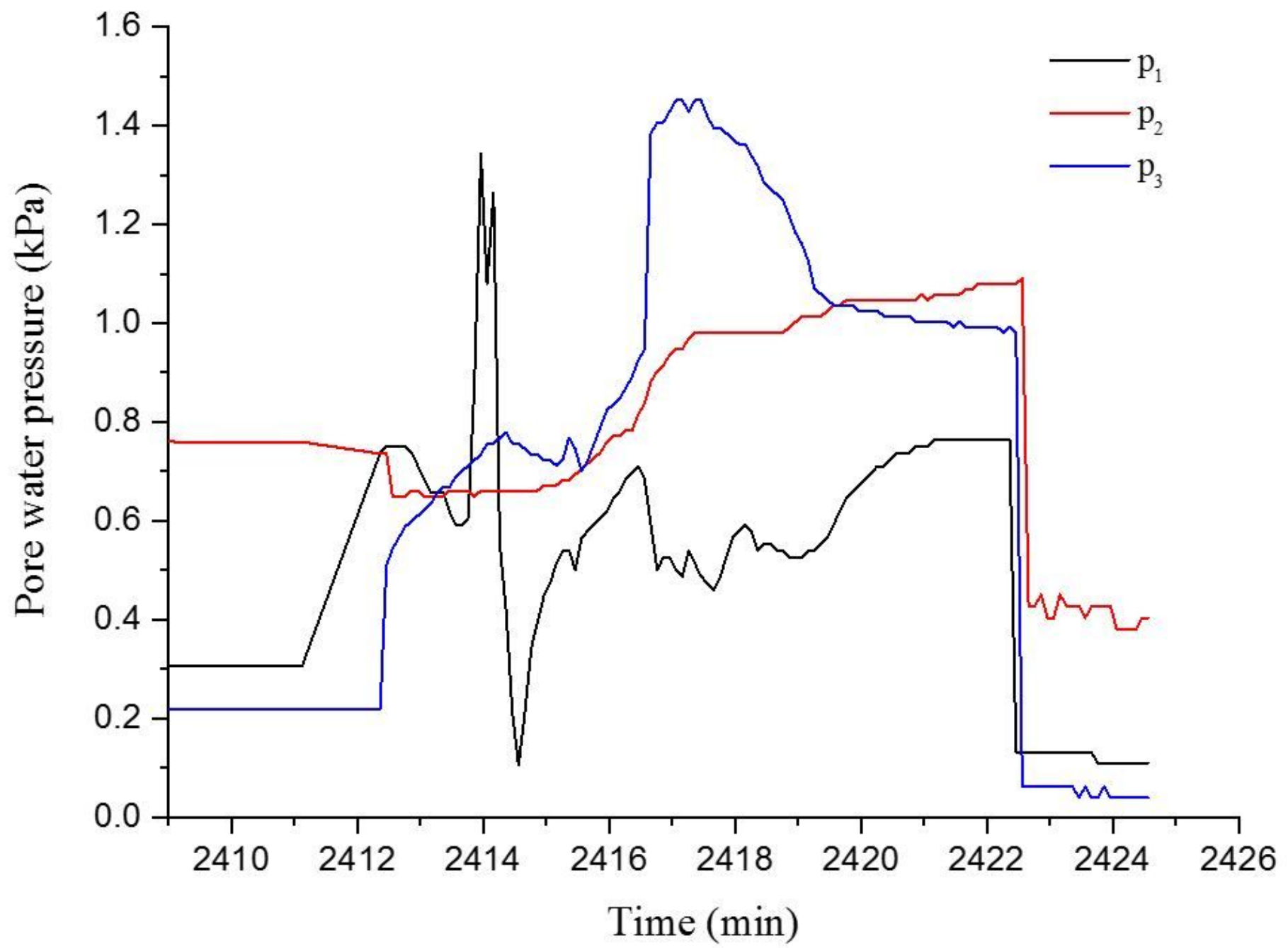

Figure 8

Variation of pore water pressure during landslide failure 


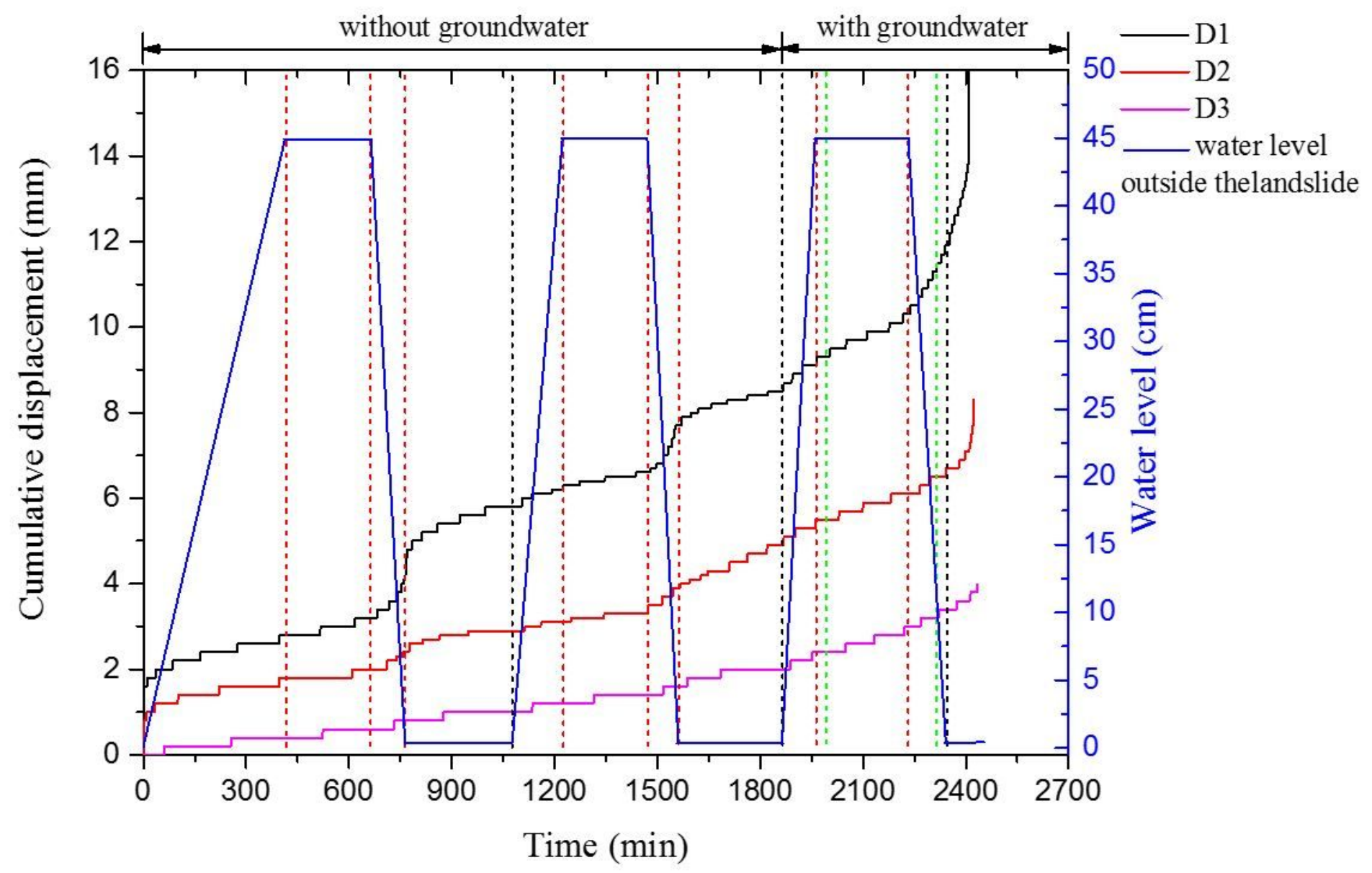

Figure 9

Variation of cumulative displacement under reservoir water level fluctuations 


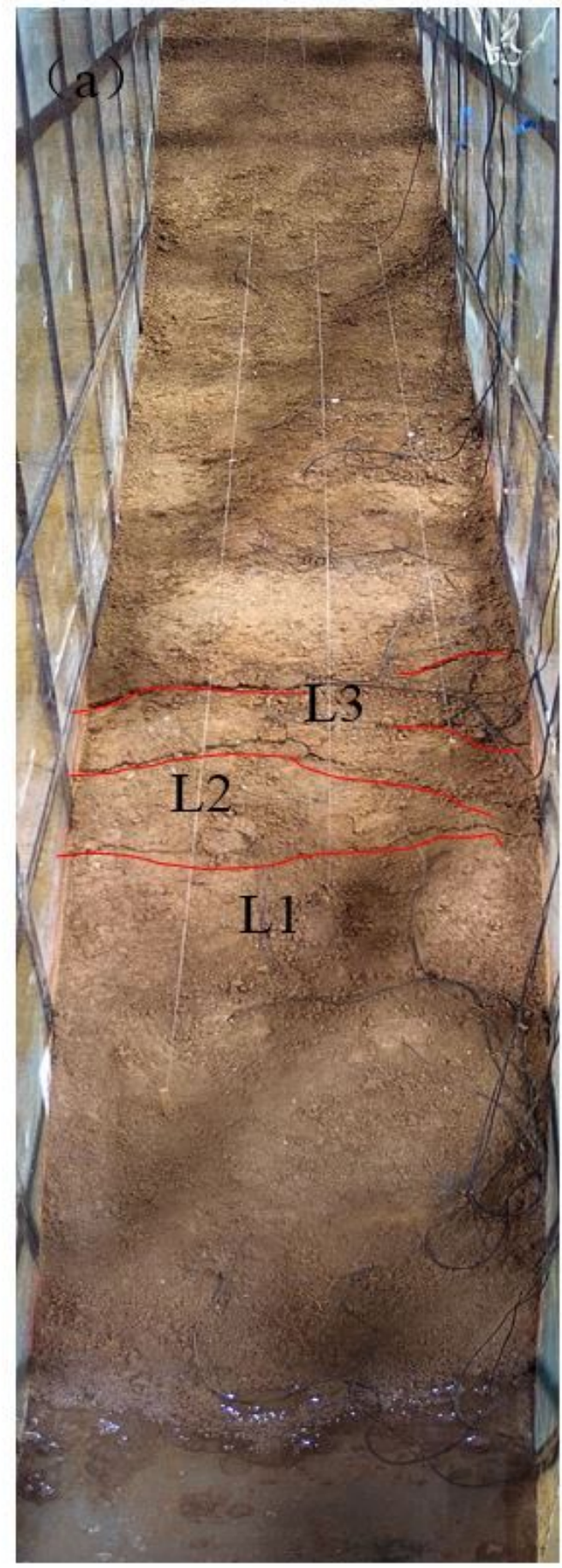

(a)

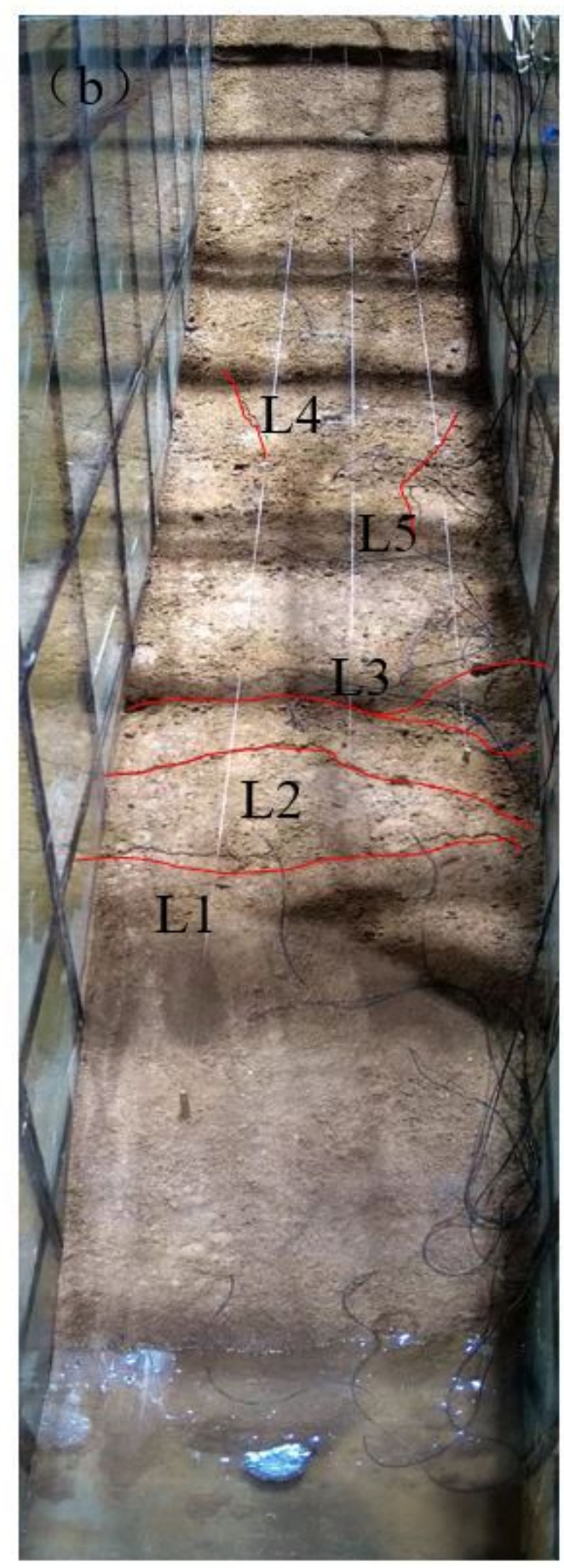

(b)

\section{Figure 10}

Failure characteristics of landslides without groundwater, (a) the first test, (b) the second test 

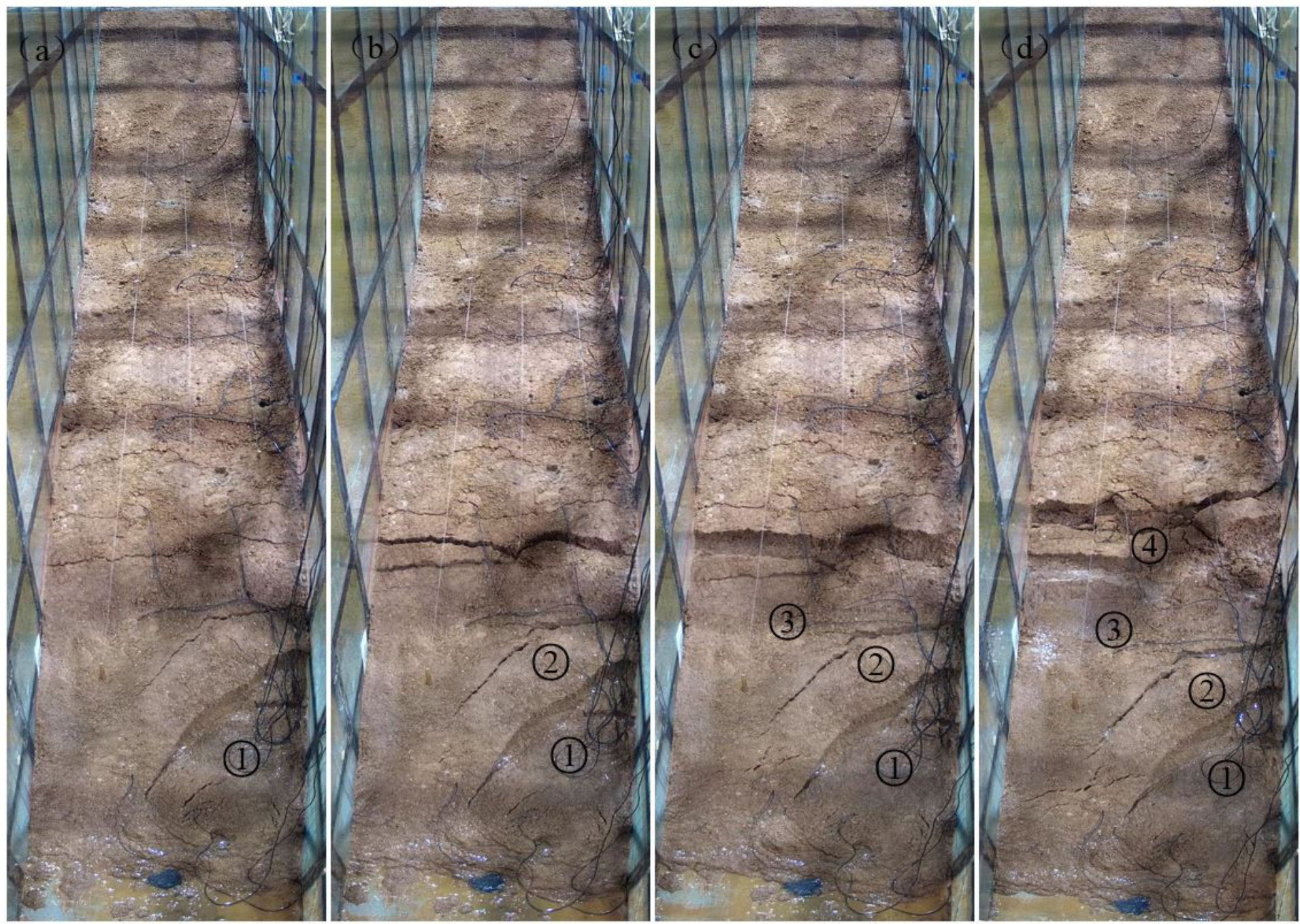

Figure 11

Failure characteristics of landslides with groundwater 


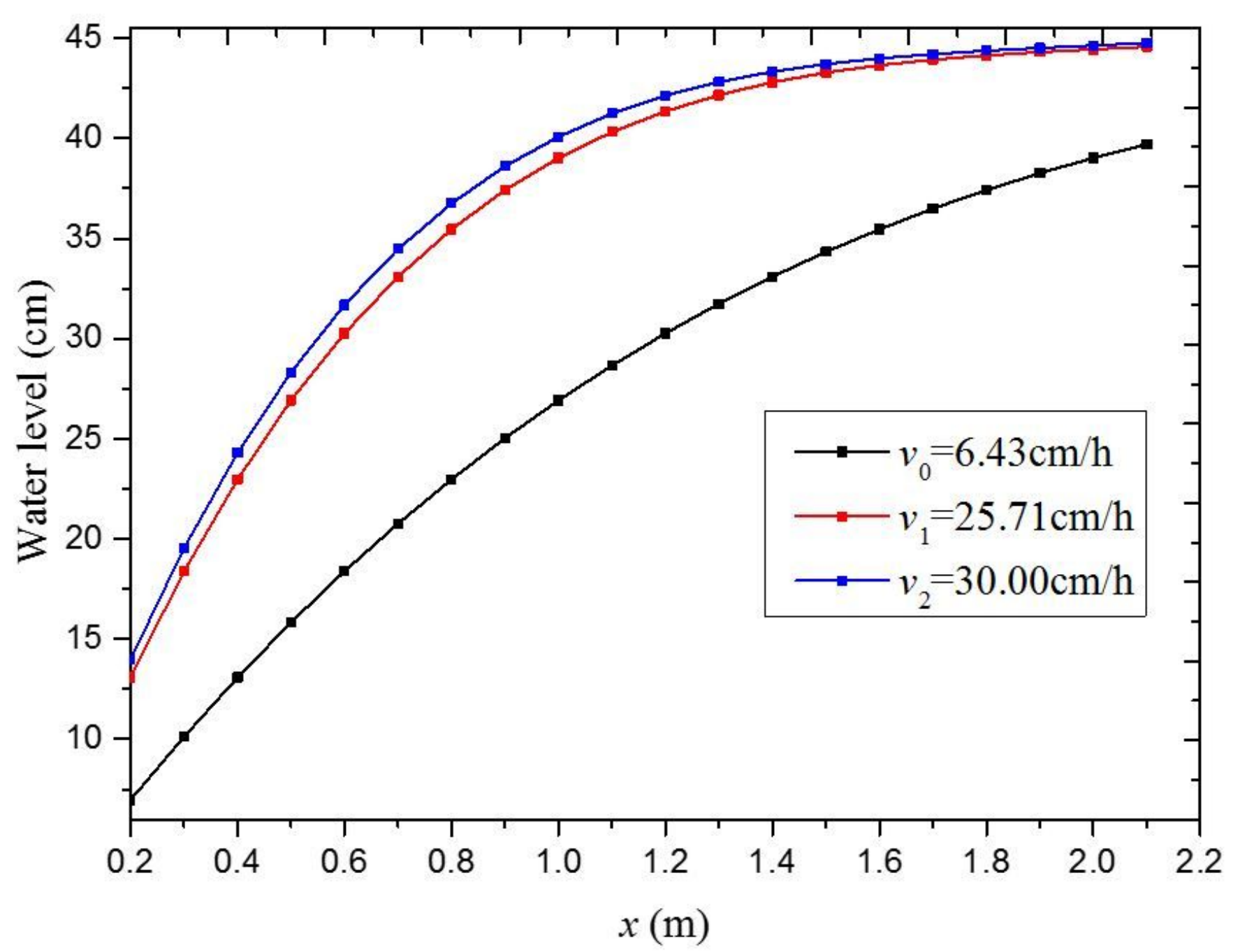

Figure 12

Groundwater level of different fall speed after the fall of reservoir water level
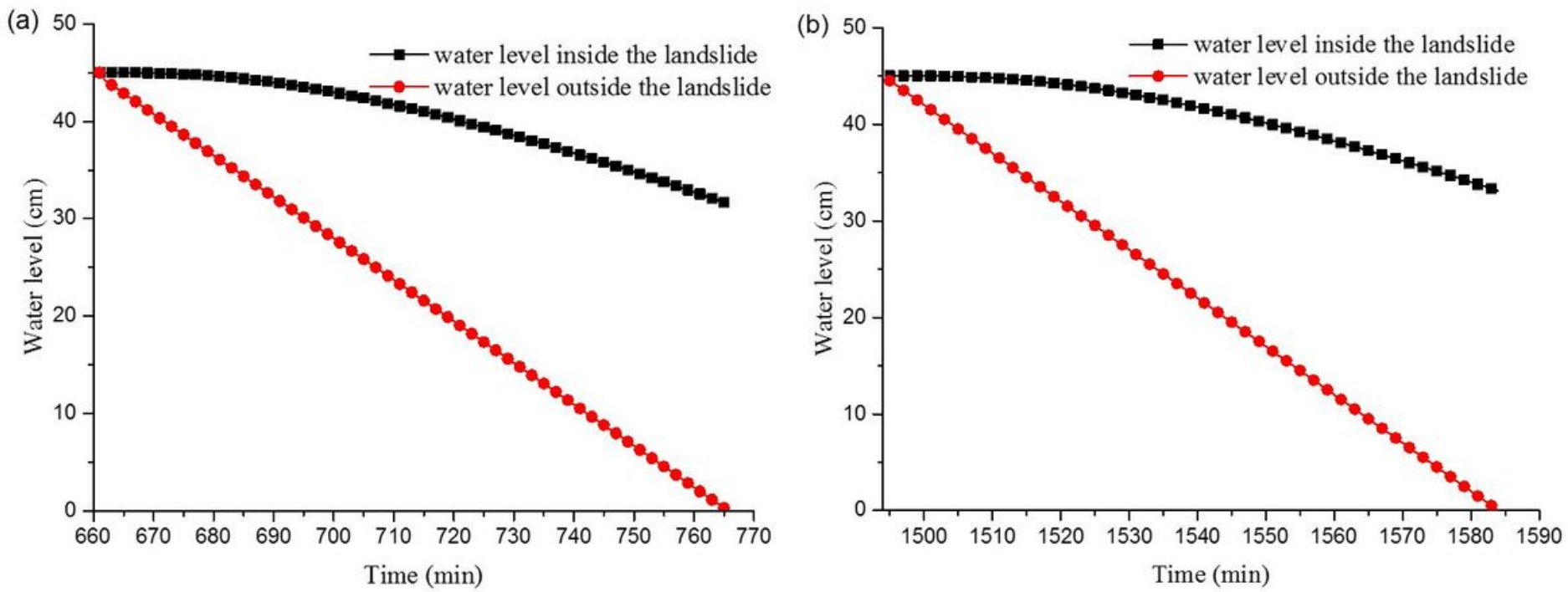

Figure 13 
Variations of groundwater level inside the landslide and reservoir water level with different falling speeds of reservoir water level, (a) v1=25.71 cm/h, (b) v2=30.00 cm/h
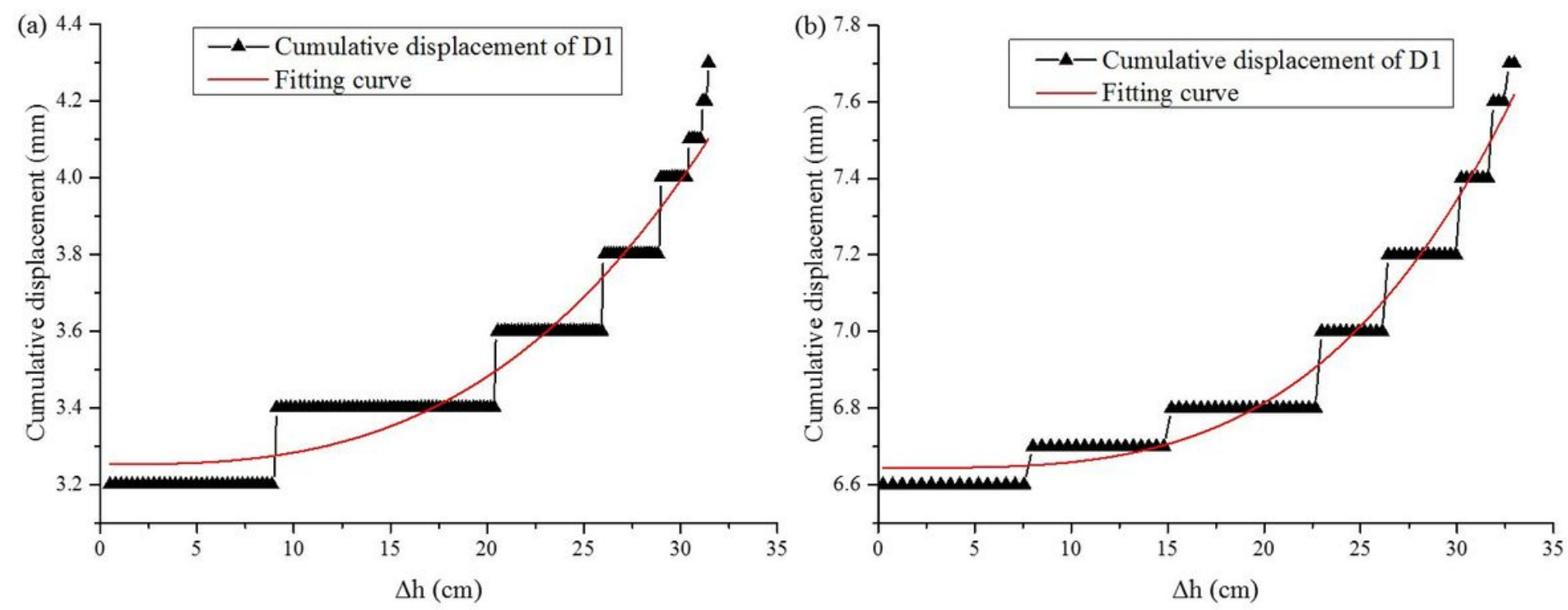

Figure 14

Variation of landslide displacement with the difference of water level between inside the landslide and the reservoir water level under different falling speed (a) $v 1=25.71 \mathrm{~cm} / \mathrm{h},(\mathrm{b}) \mathrm{v} 2=30.00 \mathrm{~cm} / \mathrm{h}$ 


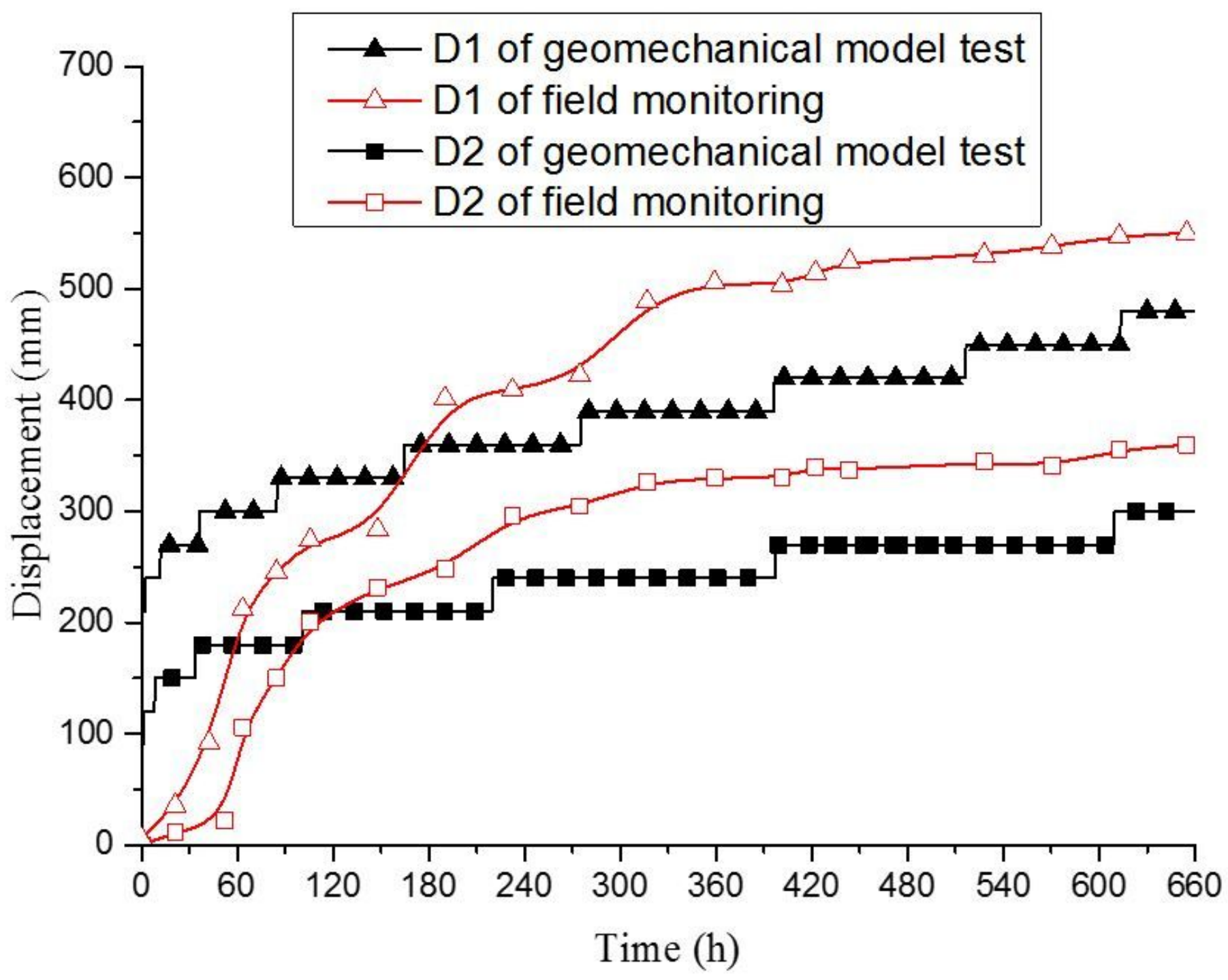

Figure 15

Comparison between the physical test displacement and field monitoring displacement during the reservoir water level rise 